\title{
Works and Networks of mkhas pa Dri med. On the Illustrations of 16th Century Tibetan Printed Books
}

\author{
Marta Sernesi
}

The illustrations of Tibetan printed books are a strikingly understudied issue, considered the wealth of data available to scrutiny. Indeed, while other material aspects of Tibetan books, such as wooden covers or manuscript illuminations, have received some attention, only few contributions address specifically the images in blockprinted texts. Moreover, Tibetan book illuminations have been usually studied in terms of their stylistic or iconographic features, while historians, specialists of textual studies, and even researchers particularly concerned with the history of the Tibetan book have so far mostly neglected the topic, to the extent that detailed and learned catalogues of Tibetan texts don't even mention the illustrations. However, the illustrations constitute an integral part of the book, considered both as a material object and as an intellectual product. ${ }^{1}$

In order to approach this issue, I have chosen to present a case study on a Tibetan master artist active during the first half of the 16th century in the Western Tibetan kingdom of Mang yul Gung thang. mKhas pa Dri med is known especially for impressive illustrations of blockprinted books, in that distinctive style that readily allows to recognize volumes produced at the time in the area. ${ }^{2} \mathrm{He}$ was among the foremost artists of his time, as may be deduced from the prestigious commissions received from the royal family, and his career in book illustration may be now well documented during the 1520s, 30s, and 40 s. Unfortunately, however, no other extant work, such as scroll painting, mural or sculpture, may be attributed to him and is available for study. Therefore, aspects of his craftsmanship - such as the use of colour - and the full scope of his artistic output, may not be evaluated. Also the crucial issue of the relation-

1 For previous studies treating the illustrations of Tibetan blockprinted texts, see Karmay 1975; Imaeda 1977; Jackson 1996: 122-31, 301-14, 375-7; De Rossi Filibeck 2002. For a catalogue that treats with particular attention the illustrations, see Everding 2015.

2 For earlier mentions of his work, see Jackson 1996: 122; Ehrhard 2000: 71, 74, 76. On the epithet mkhas pa (literally 'skilled' or 'learned') meaning artist, see Jackson 1996: 138, n. 302.

(C) MARTA SERNESI, 2016 | DOI 10.1163/9789004316256_017

This is an open access chapter distributed under the terms of the Creative Commons Attribution-

Noncommercial 3.0 Unported (CC-BY-NC 3.0) License. 
ship between book illustration and cognate arts - painting in primis, but also scribing, engraving, goldsmithry or inlay - may not be explored.

A recent Tibetan cultural history of Mang yul Gung thang mentions the first half of the 16th century as an extraordinary time for the flourishing of the arts in the kingdom, and in particular as the golden age of blockprinting, and states: ${ }^{3}$

In each region the pictorial arts spread in different ways. Because of this, also the art of illustrating the wooden book covers developed in different ways. mKhas pa Dri med from Gung thang, and the other figurative artists [working] in the craft of carving the printing blocks [that developed] in the sKyid grong district, displayed a wonderful art of book illustration, [with] a variety of appearances and postures of images of the Buddhas [inserted] on the left and right side of the books['folios]. Following the emergence of this tradition, gradually everywhere in Tibet it was widely famed how [the skill of] carving book illustrations had spread in the district of sKyid grong, and how [in that region] there were many different printing skills. Many works bearing woodcut illustrations in black and white of such high value are still preserved in the district of sKyid grong to the present day, as it is elucidated in many related reference materials. ${ }^{4}$

Therefore, the production of $m k$ has $p a$ Dri med seems as a privileged point of departure to explore the flourishing of printing skills in Mang yul Gung thang, the different aspects of the trade, the composition of the printing workshops, and the specific issue of book illustrations.

3 Mang yul gung thang gi rig gnas lo rgyus, by Gung thang bstan 'dzin nor bu, Bod ljongs mi dmangs dpe skrun khang, 2012, pp. 199-203, 518-21. The author quotes in particular the colophon of Klong chen rab 'byams pa's Theg mchog mdzod, realized in 1533 and illustrated by mkhas pa Dri med, on which see below.

4 Mang yul Gung thang gi rig gnas lo rgyus, pp. 520-1 (cf. also pp. 201-2): yul lung so sor ri mo'i dar khyab mi 'dra ba'i dbang gis gsung rab glegs shing gi ri mo'i sgyu rtsal yang mi 'dra ba thon yod pa red/gung thang gi mkhas pa dri med la sogs pa'i ri mo'i sgyu rtsal mkhas pa tshos skyid grong khul gyi par shing yig brkos kyi lag rtsal nang pod kyi g.yas g.yon du sangs rgyas kyi sku brnyan bzhugs stangs dang rnam 'gyur mi 'dra ba sna tshogs bar 'jug[=bcug] gi ri mo'i sgyu rtsal phun sum tshogs pa bkod srol byung ba de nas rim bzhin bod kyi sa phyogs gang sar skyid grong khul du dar ba'i bar 'jug [=bcug] gi ri mo'i brkos dkrol dang/ par 'debs kyi lag rtsal mi 'dra ba mang po zhig yod pa khyab par grags / de lta bu'i rin thang che ba'i dkar nag gnyis 'brel gyi par shing ri mo'i brtsams bya mang po zhig dus da lta'i bar du'ang skyid grong khul du nyar tshags byas yod ces 'brel yod kyi dpyad gzhii yig cha mang po'i nang gsal. 
The production of a blockprinted text was a collective enterprise, involving multiple people with different competences, and an ensuing distribution of tasks. 16th century prints often bear printing colophons (par byang) that elucidate the division of labour, mentioning by name the individuals involved. ${ }^{5}$ The scribe (par yig rig byed; par yig mkhas pa) would prepare the written model (paryig) leaving adequate space on the folio for the addition of the illustrations. The images were in fact drawn separately by the artists, called le lha'i rig byed: the illustrations are termed 'chapter deities' (le lha), as they are found at the beginning and end of the volumes, thus marking internal breaks in case of multi-volume texts or multi-textual collections. After being revised and approved (zhus dag), the text would then be cut out onto the wooden blocks by the carvers (rkos byed; rkos mkhan): they may be numerous, depending on the length of the text, and they divide the work among themselves lengthwise rather than content-wise. Only the most skilful carvers could cut out the images following the artists' drawings, and therefore they are usually separately mentioned in the colophons (le lha'i rkos byed). They may also be called artists ( $m k h a s p a$ ) themselves, and may be praised for their dexterity (bzo rig mthar phyin). However, artists usually don't carve their own drawings, mkhas pa Dri med for example never figures in the colophons as a carver, and therefore we may posit that there was a clear-cut distinction between the artistpainter, who drew the image, and the artist-engraver (brkos byed mkhas pa), who cut them out. ${ }^{6} 16$ th century prints from South-Western Tibet (Mang yul Gung thang and La stod $\mathrm{lHo}$ ) often carry the signatures of the scribes on the blocks, which are called ming thang or ming yig thang: they are usually found on the lower margins of the folios, and more rarely on the top or on the lateral margins. Sometimes they indicate the number of blocks carved by the named artisan, or they state that "until this point" ('di yan) they have been carved by

5 For a detailed description of the Tibetan technique of xylographic book printing, see Jest 1961. For a discussion of the division of labor in Tibetan book production as may be evinced from $15^{\text {th }}$ and 16th century colophons, see Cabezón 2001. On the study of colophons, see also Bacot 1954, Ehrhard 2000: 69-175, and Clemente 2007.

6 In the production of woodcuts in Europe the two trades were distinct as well; see Hind 1935: 30: "In general it appears to me probable that in the earliest period as well as in the later $\mathrm{xv}$ century and during the xvi century, the cutters were a separate class from the designers, and that the designers, as later, were the painters. In the xvi century the designer, or Reisser (...), is often indicated on the print by the sign of a pen, the woodcutter by a knife"; For the distinction between the designer or painter (Reisser or Maler), and the cutter or carpenter (Schnitzer or Schreiner), see also ibid.: 82, 90-1. 
a certain individual: for this reason, F.-K. Ehrhard has proposed that these signatures could have been employed in order to calculate each worker's share of work and consequent remuneration. ${ }^{7}$

As may be gained from their titles, found in the colophons, the artisans were either administrative or military officials (bcu dpon, brgya dpon, mgon po, drung yig), or educated monastics (dge slong, dge shes, dge sbyong). Therefore, apart from the artists, they do not seem to be professional figures all-year round, but individuals with other occupations employed for specific printing projects. However, many of the names recur in the colophons, indicating that their skill was appreciated and sought-after, and in practice ensured them frequent work. The same artisans are found contributing to projects realized in different areas of the kingdom (Gung thang, sKyid grong, Lan 'de[/dhe]), and by distinct religious institutions (e.g. Bo dong, Sa skya, bKa' brgyud), which suggests mobility, although within regional scope. We are in fact witnessing a distinct phase in the development of the specialized craftsmanship required for xylographic bookprinting, and at this time the trade was probably valued in good esteem: gradually printing skills will be equated to other artisanal labours, the workers' names will disappear from the books, and large and productive printing houses, with substantial manpower at their disposal, will be established.

The most important figure of the workshop was the project leader (do dam $p a$ ), who was responsible for planning and executing the printing enterprise. He needed leadership abilities to choose, summon, and organise the artists and workers, and entrepreneurial skills to raise all the needed funding and collect the materials, such as wood, paper, and ink. The project leader could act on his own initiative, raising the needed resources from his powerful acquaintances, through alms rounds, or drawing from the wealth of his religious institution. Most often, he would also direct other kinds of projects, such as the realization of statues, paintings, and murals, building constructions or renovations. If he was particularly renown for his skills, he could act at the exhortation of the royal family, who would entrust him with the duty of realizing projects conceived for specific occasions. This is the case of the Bo dong master Chos dbang rgyal mtshan (1484-1549), who supervised many of the projects illustrated by Dri med, and who was repeatedly summoned by the royal family of

7 The practice has been compared to a parallel one employed in Southern Sung printing (on which see e.g. Drège 1991: 101); see Ehrhard 2000: 69-70. The printing colophons of the works may refer to the carvers' signatures in order to identify the workers involved, by phrases such as rang rang sug rjes so sor gsal, rang rang lag rjes so so'i thang na gsal, rang rang sug rjes ming yig thang na gsal, rang rang sug rjes rang rang thang na gsal, sug rjes ming rnams rang rang thang na gsal. 
Mang yul Gung thang. ${ }^{8}$ Often the project leader and his closest collaborators are mentioned in the colophons among the artisans, acting as scribes or carvers. This shows how the capacity of taking a major role in the realization of projects such as prints, and closely supervise their execution, implied a firsthand knowledge of the crafts (bzo rig) and the technology involved. In fact, there is evidence that Chos dbang rgyal mtshan trained groups of carvers at his hermitage, teaching them the artisanal skills alongside the Buddhist doctrine. His Collected Songs ( $m$ Gur 'bum) record religious instructions written at Kun gsal gang po che and addressed to a group of six 'realized practitioners' (rtogs ldan) who were at the time studying the trade of carving for printing purposes (spar brkos). ${ }^{9}$

The illustrations have an intimate relationship with the text that they accompany. Some volumes simply bear initial portraits of the masters with whom the text is mainly concerned: thus, for example, in the production of mkhas pa Dri med, the life story of sPrul sku Nam mkha' rgyal mtshan bears the portraits of 'Ba' ra ba rGyal mtshan dpal bzang po (1310-91) and sPrul sku Nam mkha' rgyal mtshan (1475-1530), who was considered the reincarnation of the founding master of the ' $\mathrm{Ba}$ ' ra ba lineage (Appendix text no. 5), while on the life and songs of rGod tshang pa mgon po rdo rje (1189-1258) we find the portraits of this master and of his teacher gTsang pa rgya ras ye shes rdo rje (1161-1211) (Appendix text no. 10). In richly illustrated volumes, however, the images may compose a complex system of signification in themselves, representing the complete transmission lineage of the religious cycle, the main Buddhas, bodhisattvas, and tantric deities invoked, and the specific protective deities of the instructions or of the lineage: this may be observed in the Mani bka' 'bum (Appendix text no. 1), the $b K a$ ' gdams glegs 'bam (Appendix text no. 7), and the Theg mchog mdzod (Appendix text no. 4). In these cases, the value of the images is not merely ornamental, instead the illustrations interact with the written text and integrate it in an autonomous way, conveying supplementary meaning..$^{10}$ Hence, the question of the planning of the iconographic

8 For the life of this master and his printing activities, see Ehrhard 2000: 23-50.

9 See Chos rje dbang rgyal ba'i slob ma rtogs ldan drug la brkos slob dus gdams pa, in $m G$ ur 'bum zhal gdams bslab bya'i skor, NGMPP L 65/5, fols. 155a-156b; Ehrhard 2000: 79, n. 20. Incidentally, the six were disciples of mkhas grub rtogs ldan gyi rgyal po dBang phyug rgyal mtshan, himself a disciple of gTsang smyon Heruka (1452-1507). dBang phyug rgyal mtshan was active in neighbouring La stod $\mathrm{lHo}$, where he composed, at the request of his master's consort Kun tu bzang mo, the biographies of Tilopa and Nāropa.

10 The question of the relationship between images and text is too wide and complex to be addressed here; see e.g. Drège 1999 for a pertinent discussion revolving around Chinese texts from Dunhuang. See Sernesi 2015 for the study of the illustrations of the $b K a^{\prime}$ gdams 
system, and the related issue of the role of the artist in the process, arises. It may be suggested that the subject of the illustrations and their overall order were planned by the project leader - perhaps in concert with the main donor, such as the noble person in case of royal commissions, who could have specific requests. Indeed, the project leader was responsible for the whole planning of the work, from the location or production of an appropriate manuscript model, to the choice of artisans, to fund raising and the administration of the financial resources, to the consecration of the blocks and the distribution of the prints. Hence, he was in fact wholly responsible for the conception and the realization of the book, and this would logically include the plan of the illustrations (inventio), determined on the basis of his knowledge of the text and of the religious tradition. However, the figurative language (ars), including the proportions, postures, and attires of the figures, and the details of the composition, such as the filling of the background, was the domain of the artist. He would hence translate into images the indications of the project leader, according to his painting tradition, his models, his skills and sensibility. ${ }^{11}$

Since the spread of the printing technology, the blockprinted and handwritten book coexisted in Tibet: printed and manuscript copies were produced side-by-side, copied one from the other and vice-versa. However, differently from what has been observed for European book culture, instances of books produced by a combination of techniques are surprisingly lacking, even for prestigious, extensively decorated editions. It is well documented how, during the early decades of printing in Europe, the mediums of movable type printing, woodblock printing, and handwriting or illumination may be found employed together in the same volume: in fact, some early printing workshops hired illuminators in order to embellish their printed volumes in a systematic way, thus fostering the trade. Also, the employ of woodcuts for inserting

glegs bam, their relationship with the textual contents, and their value as historical evidence. For the role of illustrations in assessing the dating of a blockprint, see also Sernesi 2010: 145-9.

11 This presupposes that all parties shared the knowledge of an established iconographic tradition. For the distinction between inventio and sola ars, see e.g. Settis 2005: 6-7, who, discussing the case of medieval icons, remarks that this distinction reflects a common practice at the time, and that it presupposes the actual existence of a long-lasting iconographic tradition. 
decorated initials or illustrations within books printed with movable type soon became common, while sets of illustrations produced as xylographs or copper incisions would be printed and sold, to be inserted within or glued on either printed or handwritten books. And alongside blockbooks, i.e. books entirely produced from wooden blocks, are collections of woodcuts bearing handwritten or typeset captions or explicative texts. ${ }^{12}$ In Tibet, on the other hand, these combinations seem to have been extremely rare, and there is no evidence, to my knowledge, pointing to a production of images independent from the text to be illustrated, meant to be employed to decorate different volumes, as in the 15th-16th century European book market.

A singular case may be brought to attention as a somewhat isolated example for the moment, and that is the Collected Works of sGam po pa (Dwags po $b k a^{\prime}$ 'bum) printed at Dwags la sgam po in 1520 . Indeed, one full copy of the collection has been thoroughly decorated by hand: while at the beginning of the first volume (KA) we find the expected blockprinted illustrations, these are lacking in the following volumes, and the blank spaces on the initial folios allocated for the purpose have been filled, for the most part, with illuminations painted by hand. On the other hand, one copy of the Collected Works of sGam po pa printed from the blocks prepared in Mang yul Gung thang in 1572 shows the same illustrations, repeated, to decorate the initial folio of the different volumes: this shows that at least in this case the images were produced in a series in order to be employed multiple times. ${ }^{13}$ However, both these strategies of dec-

12 For the interaction and non-exclusive employ of manuscript, xylography, and typography in the production of 15 th century volumes, see McKitterick 2003, especially chapter 3 treating the illustrations. Cf. also Bühler 196o: 66-93, who notes "that it was quite immaterial to the fifteenth-century owner how his books were produced or decorated, whether manually or mechanically. The artist could copy the woodcutter - and the scribes and the woodcutters could imitate the printers, or vice versa - and it was all the same to the contemporary purchaser. The fifteenth-century book, then, cannot logically or properly be segregated into those neat categories so dear to the heart of Library Schools: the autonomous departments of manuscripts and printed books." (p. 68). For the significant increase of miniaturists in Venice in the late 15th century, and their collaboration with printers in order to decorate printed books on big scale, leaving the space for the buyer to eventually personalize the volume, see Armstrong 1991. For woodcut initials, see Donati 1978 and references quoted therein.

13 For the illuminated copy of the Dwags po bka' 'bum, see dPal brtsegs bod yig dpe rnying zhib 'jug khang, Bod kyi shing spar lag rtsal gyi byung rim mdor bsdus, Bod ljongs bod yig dpe rnying dpe skrun khang, 2013, DVD 2, no. 46. A copy of the collection printed from the same blocks has been filmed by the NGMPP: it has the same initial woodcuts at the beginning of vol. KA, and then empty spaces in the initial folios of each subsequent volume; NGMPP Reel no. L 594/1-595/1-596/1. Interestingly enough, the local monastic 
orating the blockprinted books - painted illuminations or repeated woodcut illustrations - are to my knowledge rarely employed, and most commonly we find the illustrations prepared for their specific purpose and carved at the appropriate place of the block. A fairly common practice in Tibet was to colour the woodcuts by hand, in order to enhance their aesthetic quality. Indeed, among the copies produced from a given set of blocks, the first samples (par phud) were destined to the main donors and sent as prestigious gifts to high officials and prelates, and therefore were further enriched when compared to later prints from the same blocks. The copies destined to the highest recipients were meticulously executed from brand new blocks, could be embellished with colour, and then splendidly wrapped; also the wooden boards serving as book covers would be decorated by paint, carvings, or inlay, perhaps by the same artists engaged in the printing project. ${ }^{14}$ These embellishments, however, could also be done at a later stage on behalf of a subsequent owner of the text, or requested by an individual upon commanding a print from the existing blocks - which could be in use for centuries - while of course wooden covers could be re-employed and switched easily, so that we cannot mechanically date all the aspects of the decorated book at the time of the carving of the blocks, nor attribute them to the same individuals.

Overall, in terms of format, there is an obvious continuity between manuscript and print. Indeed, there is even a case of a blockprinted text bearing such a conservative formal feature as the mark for the string-holes. ${ }^{15}$ Also, there is evidence of skilled scribes who worked at the written models used for carving printing blocks, who were also active in preparing luxury manuscripts editions. ${ }^{16}$ However, when compared to prestigious manuscript editions,

history states that this collection was printed "with many initial illustrations" ( $d b u$ la mang po dang bcas par du bsgrubs). For the context of production of this edition, and of the new edition produced in Mang yul Gung thang in 1572 by Byams pa phun tshogs (1503-86), see Sernesi forthcoming. The copy of this later edition filmed by the NGMPP as reels E 1991/10-1992/27 added lateral images at fol. 1 b of several texts (repeating them always the same), which are absent from another copy of the print, filmed as NGMPP reel L 118/3-119/1.

14 For Tibetan book covers, see Grönbold 1991, 2002; Klimburg-Salter 1990; Selig-Brown 2012.

15 For this text, printed in 1407 in La stod lHo, see Diemberger 2012, and Porong Dawa in this volume. The real discontinuity in terms of format may be observed between the scroll and the codex (or the scroll and the pothi); on the largely forgotten or unacknowledged 'revolution' of the codex, see Chartier 2007: 407-8.

16 The master scribe (dponyig) from the area of sNyings called Thugs rje skyabs pa acted as scribe (yig mkhan) for the printed edition of the biography of Nam mkha' rgyal mtshan (text no. 5 in the Appendix), and for the print of the biography of bsTan gnyis gling pa 
printed editions show some minor formal discontinuities with their model. The most important difference may be observed in the title page. Indeed, luxury manuscript editions usually begin with a calligraphed page: only a few syllables of the title or incipit are inscribed in bigger size, often in metal ink (prepared from gold or silver) on dark paper; this is followed by a second page of calligraphy, also illustrated. Therefore, calligraphy and precious substances are employed, alongside illuminations, to lend value to the manuscript copy. ${ }^{17}$ The printed book, on the other hand, needs to discard both these means, and recurs solely to pictures and drawings as enriching devices. Thus, the quality and number of illustrations may indicate the level of the book commission: royal productions were richly decorated by the best artists of the kingdom, while middle-scale, local productions may bear illustrations but in minor quantity and often of inferior execution. Also, new formal solutions are conceived: in this context we may understand the appearance of the decorated title-page so distinctive of South-Western Tibetan prestigious blockprints, bearing the full title of the text within a lavish composition of lotus throne, vines and stylized foliage. ${ }^{18}$ Then, with the verso of the first folio, the text begins: this is illustrated, and usually the script is neater and less dense, with one less line of script than in the rest of the volume, but there is no more use of calligraphic embellishments. The quality and the number of the illustrations become the true criteria of luxury.

\section{The Tradition of sMan thang pa}

It is widely known everywhere that, at the time of the rule of the Phag mo gru pa, the painting tradition of sMan thang [pa] greatly spread and developed in the district of mNga' ris Gung thang, and that [in that region] there were also many famous artists skilled in [that] painting

(text no. 6 in the Apendix). Chos dbang rgyal mtshan imparted instructions to the same individual at the time when he was preparing a golden manuscript; see $d$ Ponyig thugs rje gser yig 'bri dus gdams pa, in mGur 'bum zhal gdams bslab bya'i skor, NGM PP L 65/5, fols. 167b-168b; Ehrhard 2000: 74, n. 12.

17 For the production of luxury manuscript editions with the employ of precious metals and stones, and the realization of the initial pages in relief type script (yi ge lto gar, gser bris lto gar), see e.g. Cüppers 2010.

18 In this regards, it may be interesting to note how the title page of books - bearing the title, author name, printing house and year of printing - was rare in the European manuscript culture, and developed gradually after the beginning of the printing press, to be found opening incunabula from the 1480s; see e.g. Hirsch 1978; Labarre 1982. 
tradition. The artist Dri med from Gung thang was one [such] skilled painter who adhered to the tradition of sMan thang: the works illustrated by him in that way, and the great knowledge of pictorial arts, filled everywhere the land of mNga' ris Gung thang, making everywhere weaver the banner of fame. ${ }^{19}$

mKhas pa Dri med is known as a follower of the painting tradition inaugurated by sMan bla don grub, known from his birthplace as 'the master from sMan thang' (sMan thang pa/ sMan thang chen po). He flourished in the mid15th century (1450s-70s or 8os), and is recognized as one of the earliest artists to create a unique style of Tibetan painting, called the sMan thang tradition (sMan ris/ sMan thang lugs). ${ }^{20}$ No mural or scroll attributed to the master or his direct pupils has been so far available for study, and also for this reason the production of Dri med has received attention as the earliest datable evidence of the tradition. ${ }^{21}$

sMan thang pa was a native of lHo brag, and was trained in the Central Tibetan region of gTsang: his main teachers were dPal 'byor rin chen and bSod nams dpal 'byor, both from gNas rnying, and active in rGyal mkhar rtse during the 1430s, where they signed murals at both the gTsug lag khang and the sKu 'bum stūpa sponsored by the ruler Rab brtan kun bzang 'phags (r. 1412-1442), also known as a donor of early printing projects. ${ }^{22}$ The magnificent paintings

19 Mang yul gung thang gi rig gnas lo rgyus (as in n. 3), p. 199: phag gru'i dbang bsgyur byed pa'i dus rim de'i nang/ mnga' ris gung thang khul du sman thang lugs kyi ri mo'i sgyu rtsal mang po dar khyab chen po byung bar ma zad/sgyu rtsal ri mor mkhas pa'i mi sna grags can yang mang po byung yod ces sa khyab rdo khyab tu grags/gung thang gi mkhas pa dri med ni sman thang lugs la dad zhen gnang mkhan gyi ri mo ba mkhas can zhig yin par ma zad/ khong gis de'i thad kyi ri mo'i brtsams bya dang/ de min ri mo'i sgyu rtsal gyi rig gnas mang po zhig mnga' ris gung thang gi sa cha gang sar khyab cing snyan grags kyi ba dan gang sar g.yo bar byas.

20 For the dating of sMan bla don grub see Jackson 1997: 254-7.

21 Note, however, that "A few murals attributed to menla Döndrub are reported to have survived in Tibet. According to the account of a recent artist at Tashilhunpo, the original murals painted by Menthangpa in the great assembly hall are still extant. These include those of Vajradhara surrounded by the eighty great adepts, of the Buddha Sākyamuni surrounded by the sixteen arhats, and of the Twelve Great Deeds of the Buddha. It has not been possible to obtain photographs of these works...": Jackson 1997: 257, quoting Lobsang Phuntshok, Bzo rig pa'i bstan bcos la sangs rgyas byang sems dang yi dam zhi khro'i lha tshogs kyi cha tshad gsal ba'i ri mo don ldan kun gsal me long, Beijing, 1993, p. 5 . See Tucci 1941; Ricca and Lo Bue 1993: 20, 250, 290, 303; Jackson 1996: 109-11; von Schroeder 2006. For the ruler of rGyal mkhar rtse, see Lo Bue 1992; for the printing projects sponsored by Rab brtan kun bzang 'phags, see Ehrhard 2000: 11-2. 
of these constructions were considered by Tucci as the earliest example of a true Tibetan style, as they part from the earlier and contemporary works directly indebted to the Pāla or Newar traditions. ${ }^{23}$ Ricca describes the cycle of the eighty-four mahāsiddhas painted by dPal 'byor rin chen in the Lam 'bras lha khang in the upper storey of the gTsug lag khang, as follows:

These paintings are distinguished for their bright colours and for the particularly lively postures of the figures, as well as for the free association and arrangement in space of individual elements (siddhas, prajñās and trees) with luxuriant flowers, shreds of clouds and ritual objects. The countenances of the siddhas are rendered with great taste and refinement. And the virtuosity of the artist is evident in the shading technique sometimes used to create realism in the musculature. The full artistic maturity attained by the Tibetan master is evident, too, in the harmonious way in which the Newar backgrounds stewn with small corollas are beautifully integrated with the large flowers and leaves, and with the clouds of Chinese origin. The same masterly skill is revealed in the treatment of the bodies of the yogins and in the well-draped garments of the monks, as well as in the portrayals of elegant styled animals. ${ }^{24}$

The murals are praised for the lively postures and the refined execution of the figures, and for the free arrangement of the elements in the composition. Against the dark Newar background are disposed coloured decorative elements, such as large flowers and clouds, the latter showing a noticeable Chinese influence. These innovations were fostered and brought to perfection by sMan thang pa. According to tradition, he designed slender bodies, with long necks and limbs, and especially a longer lower body, portraying the figures in natural, relaxed postures; in particular, in his manual on iconography " $[\mathrm{h}] \mathrm{e}$ states that figures of bodhisattvas should be long and slander, and those of wrathful deities short and stout in order to distinguish one type from the other." ${ }^{25} \mathrm{His}$ style is characterized by prevailing tones of malachite and azurite, and a lavish use of gold to add brightness to the painting, in contrast with the prevailing red-orange hues of Newar-influenced (Bal-bris) works, prevailing in the murals

\footnotetext{
23 Tucci 1949: 280.

24 Ricca 1997: 208-9; he remarks that dPal 'byor rin chen painted also the portrait of 'Jam dbyangs Rin chen rgyal mtshan (1364-1422, abbot of gNas rnying) in chapel $4 \mathrm{~S}_{2}$ of the sKu 'bum, and also decorated its chapel $2 \mathrm{Sb}$, and in 1418 had prepared the drawings for an appliqué scroll at rGyal mkhar rtse. 
painted by dPal 'byor rin chen. sMan bla don grub is best known for complex compositions against extensively decorated backgrounds: natural landscapes rich in water, clouds, and plants, which incorporate Chinese motifs. ${ }^{26}$

It is said that sMan bla don grub was directly exposed to Chinese art, and indeed, at the time, Tibet-Ming relationships engendered the travel of people, and the ensuing exchange of goods and artefacts. In this way, Chinese painted scrolls, textiles, and bronzes reached Central Tibet as gifts to high hierarchs, and were destined to enrich the monasteries' treasure troves. Under the same circumstances, the Yongle Tibetan bKa' 'gyur, printed in 1410 upon the order of emperor Chengzu, was sent from the Chinese court to the Sa skya master Chos rje Kun dga' bkra shis (1349-1425), and to Tsong kha pa's disciple Byams chen chos rje Shākya ye shes (1352/4-1435): this is considered one of the triggers for the $15^{\text {th }}$ century widespread adoption of the woodblock printing technique in Central Tibet. ${ }^{27}$

On the other hand, sMan thang pa's reception of Chinese visual culture was also mediated by the synthesis attempted at rGyal mkhar rtse by his own masters, and was harmonised with other elements in order to create a new Tibetan stylistic blend. sMan thang pa became increasingly famous in gTsang, where he trained his sons and pupils, who were called upon to contribute to the main commissions in Central Tibet in the latter half of the century: in particular, sMan thang pa was active at bKra shis lhun po upon request of dGe 'dun grub (1391-1474), and he himself or his sons and pupils were working at gSer mdog can for Śākya mchog ldan (1428-1507), and later also at Yangs pa can for the 4th Zhwa dmar pa Chos grags ye shes $\left(1453^{-1524)} .^{28}\right.$

sMan thang pa's main iconographic treatise, the Wish-fulfilling Gem explaining the measures of the bodies of the Sugatas (bDe bar gshegs pa'i sku gzugs kyi

26 A description of the sMan thang style is provided by Jackson 1996: 119, and Thaye 1997: 272-5.

27 For the relationship and exchanges between Central Tibet and the early Ming, see Sperling 1980, 1982, Wylie 1980, 1980b. For the Yongle bKa' 'gyur, see Imaeda 1977, Silk 1996. For Tibeto-Chinese visual culture at the time, see for instance Karmay 1975, Watt and Leidy 2005, Weidner 2009.

28 At bKra shis lhun po, he worked upon request of dGe 'dun grub (1391-1474) in 1458, 1464, 1468-9: he painted murals on the first two occasions, supervised the realization of a large cloth-appliqué thang ka of the Buddha in 1468, and prepared a smaller cloth image of Tārā in the following year. These commissions are known from the biography of the first Dalai Lama; see Jackson 1997: 256; Jackson 1996: 114-21. For the activities at gSer mdog can, i.e. the execution of a large silken scroll depicting the Buddha Śākyamuni surrounded by the sixteen Arhats in 1491, and murals for the temple, the assembly hall, and the protector's chapel, in 1491 and 1495, see Caumanns 2013: 75-8. 
tshad kyi rab tu byed pa'i yid bzhin gyi nor bu), was written at the request of his pupils coming from dBus and gTsang, at the monastery of 'Bras yul rdzong dkar in the Rong valley in gTsang.. ${ }^{29}$ 'Bras yul Skyed mo[s] tshal had been founded by the famed Sa skya master Byams chen Rab 'byams pa Sangs rgyas 'phel (1411-1485), and had soon become a major institution, with five dependent "son monasteries" established by his students. The Sa skya communities in La stod lHo and Mang yul Gung thang had strong ties with the school's institutions in gTsang, where a copious number of monastics from these Western regions were trained. In fact, the 3 rd abbot of 'Bras yul Skyed mo[s] tshal, Nor bu phun tshogs (1450-1521), stemmed from the Khang pa family, which was settled in the village of gNas in Mang yul, and after his ordination was trained by Rab 'byams pa Sangs rgyas 'phel himself. It is safe to speculate that during his tenancy, at the beginning of the 16th century, monastics from his home region came in even greater numbers to be trained at the monastery in the Rong valley. ${ }^{30}$

\section{4}

mKhas pa Dri med

Among the youths travelling to gTsang at the time must have been also Dri med, who, however, instead of following the scholastic curriculum, sought for training in the figurative arts. If he was exposed to sMan bla don grub's work in 'Bras yul Skyed mo[s] tshal or in the other great monastic institutions where the master had painted is not known, but in any case Dri med was probably trained by a member of the painting tradition who was active in the region at the beginning of the 16th century. Indeed, the earliest testimony that we have of Dri med dates 1521, and he is already designated as one "following the tradition of the artist from sMan thang." At that time he must have already achieved some fame in his home region, as he was called to work at a major printing project commissioned by the royal house and prepared at the capital rDzong dkar, that is to say the first printed edition of the Mani bka' 'bum (fig. 15.1; Appendix text no. 1). ${ }^{31}$ It was realized in two bulky volumes enriched

29 Jackson 1996: 113, 135 n. 272; Cüppers, van der Kuijp, and Pagel 2012: 5 .

30 For Byams chen Rab 'byams pa Sangs rgyas 'phel, and the foundation and succession at Skyed tshal, see van der Kuijp 1983: 120-2. For Nor bu phun tshogs and the Khang pa family, see Ehrhard 2012: 150-2. For the location of the monastery, and neighbouring religious institutions in the Rong chu valley, see Ferrari 1958: 70.

31 For the Royal edition of the collection and its earliest reprints, see Ehrhard 2013; Sernesi forthcoming. 


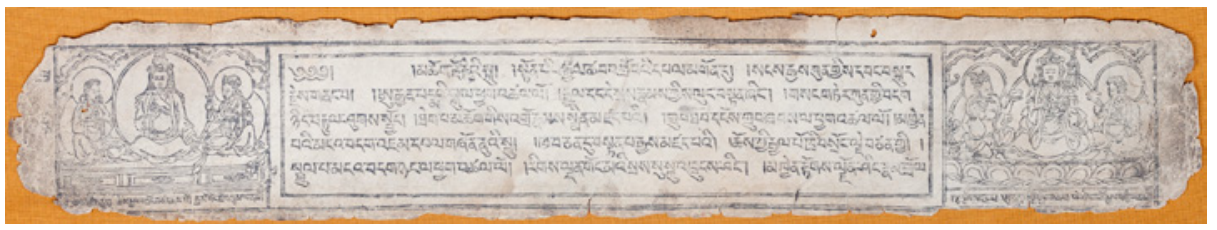

FIGURE 15.1 Royal Print of the Mani bka' 'bum, printed in 1521, vol. Ka, fol. 2a. Cambridge University Library.

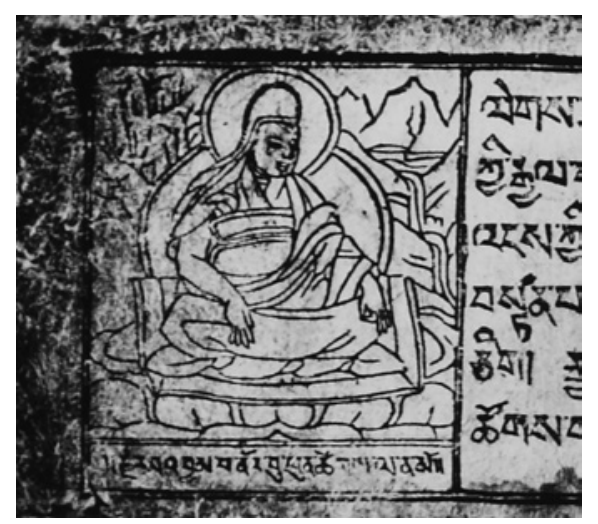

FIGURE 15.2

Portrait of Nor bu phun tshogs (1450-1521)

from the Royal Print of the Mani bka' 'bum, vol. Kha, fol. 370 b left. Kathmandu National Archives.

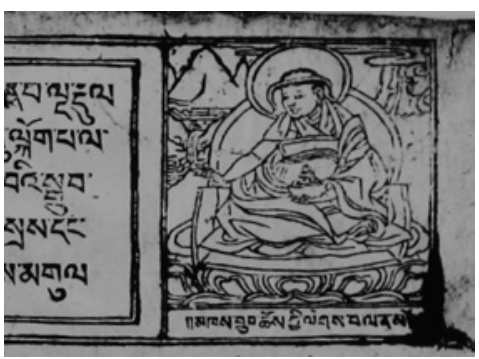

FIGURE $15 \cdot 3$

Portrait of bTsun pa Chos legs (1437-1521), from the Royal Print of the Mani bka' 'bum, vol. Kha, fol. 32ob, right. Kathmandu National Archives.

by a total of twenty-four images, drawn by Dri med and another artist from Gung thang called rDo rje mgon po: among the closing illustrations, there is also the portrait of the master Nor bu phun tshogs (fig. 15.2), who had just passed away after having served, in the latter years of his life, as the abbot of the Sa skya monastery in the capital of Gung thang, namely sGo mangs. In that same year had also passed away the teacher of Chos dbang rgyal mtshan, the Bo dong master bTsun pa Chos legs (1437-1521), who was a teacher of the king Khri Kun dga' rnam rgyal lde (d. 1524), and had been instrumental in the transmission of the Mani bka' 'bum at court: his portrait is found on the right side of 
fol. $32 \mathrm{ob}$ of the second volume of the print (fig. 15.3). Indeed, the illustrations of the collection, found at the beginning and at the end of the individual texts and running through both volumes, represent the king Srong btsan sgam po, at the origin of the teachings, and the master Padmasambhava (fol. 2a, fig. 15.1), then the treasure discoverers who compiled the scriptures, and finally the succession lineage of masters who transmitted the teachings in the kingdom. ${ }^{32}$

The master Dri med worked at least at ten more printing projects during the following twenty-five years (see complete list in the Appendix). During the 1520 and 1530 s he contributed to all the major printing projects headed by the Bo dong monk Chos dbang rgyal mtshan, mostly realized at the latter's hermitage Kun gsal gang po che, either on his own initiative, or solicited by the royal family. It is probable that Dri med during this time was summoned to realize other artefacts commissioned by the noble house for the palace and monasteries of the capital, but unfortunately we have no supporting evidence so far. In particular, Kun bzang Nyi zla grags pa (1514-1560), later also known as bDud 'dul mgon po lde, ascended the throne in 1529: this ruler is known as a generous donor of multiple "supports of the Buddha's body, speech and mind", and is mentioned with praise in many of the printed books of the time. ${ }^{33}$

The artist Dri med is famous principally for the illustrations of Klong chen Rab 'byams pa's Theg mchog mdzod, printed at Kun gsal gang po che in 1533, after that a manuscript of the text was brought from Central Tibet by bSod nams bkra shis, a pupil of Chos dbang rgyal mtshan. ${ }^{34}$ These images were thus realised midway between 1521, the date of his earliest works, and the date of his last signed volume, i.e. 1545. The printed volume is enriched by eight illustrations, on either side of the two opening (fol. $1 \mathrm{~b}, 2 \mathrm{a}$ ) and the two closing folios (fol. 509b-510a), all drawn solely by Dri med; bSod nams bkra shis carved himself the initial ones (Appendix text no. 4). These are among the painter's finest creations and represent perhaps the peak of his career: the lively postures of the yogins may be compared with the portraits of the siddhas painted in rGyal mkhar rtse a century earlier by dPal 'byor rin chen, while the background

The full list of illustrations is given in the Appendix, text no. 1. For the transmission of the Mani bka' 'bum in Mang yul Gung thang, see Ehrhard 2oood and Ehrhard 2013.

The Mang yul gung thang gi rig gnas lo rgyus (as in n. 3), pp. 199-200, states that the king commissioned, for the royal palace, paintings of the previous lives of the Buddha based on the dPag bsam 'khri shing (Bodhisattvāvadānakalpalatā), and paintings of the succession history of the kings of Tibet (bod kyi tsan po rim byon gyi lo rgyus).

34 For this printing project, see Ehrhard 2000:38, 73-4. For the facsimile edition, see Ehrhard 200ob. For its description and its illustrations, see also Jackson 1996: 122-5; Everding 2015, $s v$. Hs.or. 1648. For the colophon, see Everding ibid.; Ehrhard 2000: 104-14. bSod nams bkra shis was active alongside Chos dbang rgyal mtshan in many printing projects, and acted as a carver himself; see Ehrhard 2000: passim, and below. 
is filled by stylised rock boulders, trees and bushes (figs. 15.4 and 15.5). The scribe of the first part is called gTsang pa 'Od zer, while the rest was written by dge slong sGrol ma and his brother. The first scribe is originally from gTsang, an area of Mang yul Gung thang not to be confused with the central Tibetan region. This individual is qualified in the colophon as "the youngest pupil of the master scribe from mNga' ris called rDo rje dpal" (mnga' ris yig dpon rdo rje dpal zhes pa'i slob ma'i tha chungs), indicating that he was still in training at the time in question. The numerous carvers are mentioned in the colophon by name, with a number written above each one that indicates the number of blocks individually carved: evidently this served as a means of calculating their share of payment.

The contacts between Mang yul Gung thang and Central Tibet involved not only the training of monks and artisans, but also the search for manuscripts to serve as models for Western Tibetan printing projects, and the dispatch of the first copies of prestigious editions to high hierarchs in Central Tibet. These interactions had publicized the high quality of the Western Tibetan prints, which had attracted estimators from outside the kingdom. Indeed, in the Spring of 1534 Dri med was called to work at a commission that had come from Central Tibet: the print of the life and songs of the 'Ba' ra ba master sPrul sku Nam mkha' rgyal mtshan (1475-1430). It was requested to King Kun bzang nyi zla grags pa by an official of Chu shul lhun po rtse, and realized at the King's

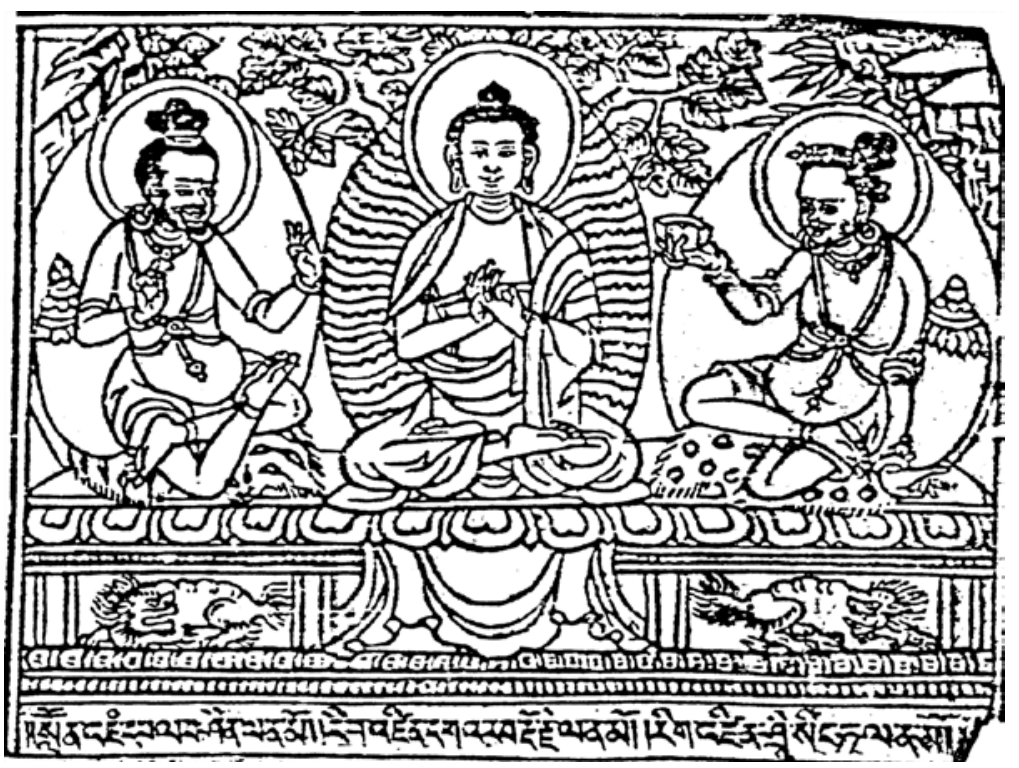

FIGURE 15.4 Illustration of the Theg mchog mdzod printed in 1533, fol. 16 right. Kathmandu National Archives. 


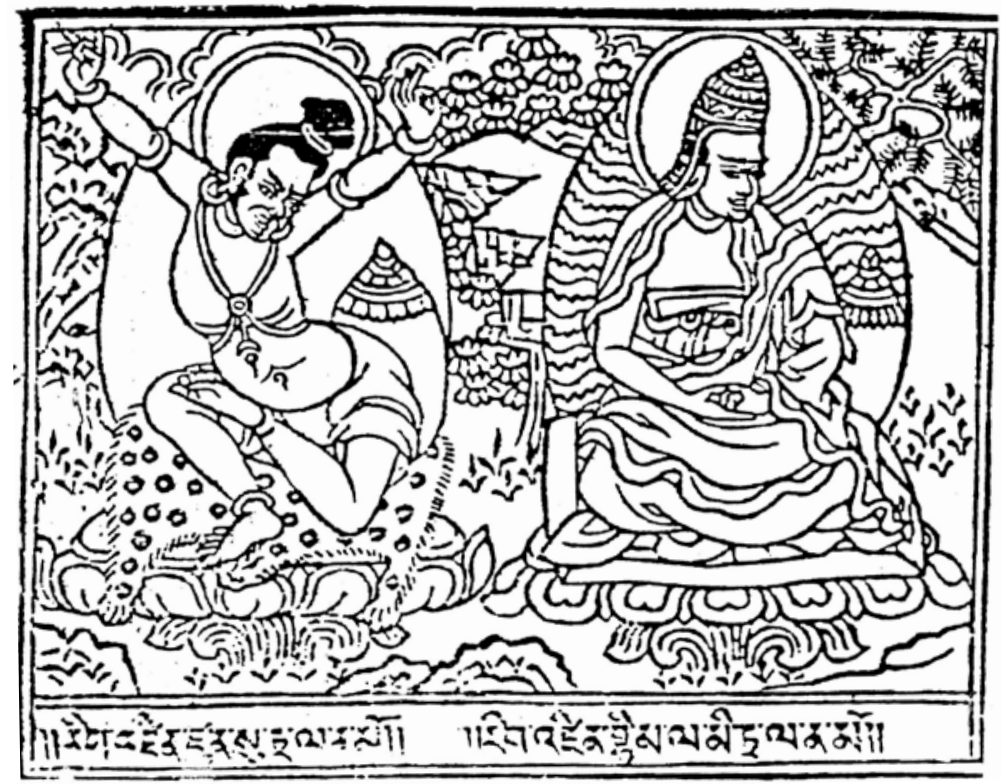

FIGURE 15.5 Illustration of the Theg mchog mdzod printed in 1533., fol. 2 a left. Kathmandu National Archives.

order, again in Kun gsal gang po che by a group of artisans headed by Chos dbang rgyal mtshan (Appendix text no. 5). The scribe was Thugs rje skyabs pa from sNyings. Dri med was involved in this project, for which he drew exquisitely detailed illustrations. After its completion, the official party travelling to Central Tibet also carried first copies (par phud) of the Theg mchog mdzod to be dispatched to the distant donors. ${ }^{35}$

Another ambitious enterprise realized at the Bo dong hermitage was the first printed edition of the bKa gdams glegs 'bam, accomplished in 1539 (Appendix text no. 7). Its two volumes are enriched by a series of portraits of the masters who compiled and transmitted the collection, partly mirroring and partly supplementing the information provided by the text itself (fig. 15.6). ${ }^{36}$ The total of forty illustrations were drawn by three artists - Dri

35 For this printing project, commissioned from afar, see Ehrhard 2000: 39; Ehrhard forthcoming: images of the text are published in the latter. Note that only a copy of the rnam thar is extant, which is numbered Kha, suggesting that the mgur 'bum constituted the first volume (Ka).

36 The illustrations are listed in the Appendix, text no. 7. For a detailed study of these illustrations and their ordering, see Sernesi 2015. On this edition, see also Eimer 1984. 

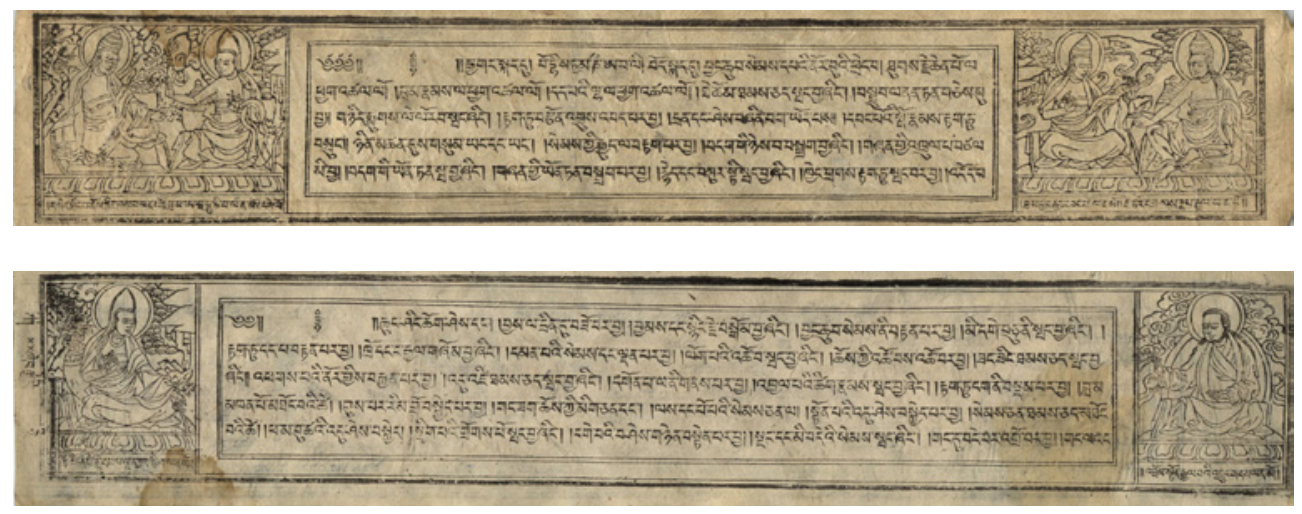

FIGURE 15.6 The bKa' gdams glegs bam printed in 1539, vol Ka, fols. $247 b$ and $248 a$. Paltsek Institute.

med, Chos dpal, and sMon lam - and were carved by bSod nams bkra shis. The latter individual, who had already realized previous projects with Chos dbang rgyal mtshan such as the Theg mchog mdzod, is called in this instance "the great artist" (mkhas pa chen po), apparently for his great skill in cutting out the elaborate illustrations. However, he is never mentioned as the person responsible for drawing the illustrations, showing how the two trades of painting and carving remained distinct. Among the scribes, figure the same that had worked at the Theg mchog mdzod, i.e. dGe slong Sgrol ma seng ge, and the above-mentioned Thugs rje skyabs pa, here called artist ( $m$ khas pa) too, all from sNyings: it has been observed how "With the help of this text we can see clearly that the regions of sNyings and gTsang were the local centres from where the scribes and carvers were first and foremost recruited" (Ehrhard 2000: 74).

During the 1540 , Dri med worked at a number of middle scale productions in the southern part of the kingdom, in sKyid grong. Two projects were realized respectively in 1540 and 1545 in the Lan 'de[/dhe] valley: the reprint of The Collected Songs of Mi la ras pa by gTsang smyon Heruka (Appendix text no. 8) and the reprint of the Life and Songs of sPrul sku Nam mkha' rgyal mtshan (Appendix text no. 9). Interestingly enough, in the colophon of the Mi la'i mgur 'bum the scribe gTsang pa 'Od zer is still qualified as "the youngest pupil of the master scribe of mNga' ris called rDo rje dpal". On the other hand, in the colophon of the Collected Songs of Nam mkha' rgyal mtshan, produced five years later, he is now simply denoted as the scribe (yig mkhan), indicating that his long training, already ongoing in 1533, was finally fulfilled by the time. In another, undated text, the same individual is called "the expert well-trained 
scribe for printing purposes" (spar yig rig byed legs sbyangs mthar son pa), showing how he eventually acquired recognition in the trade. ${ }^{37}$

In the year 1546, mkhas pa Dri med may still be found in the southern region of sKyid grong together with one mkhas pa dPal chen, at the head of the decoration project of the circumambulation path of the 'Phags pa lha khang. The renovation was supervised by the monk of royal birth lHa btsun Rin chen rnam rgyal (1473-1557). ${ }^{38}$ The latter is also well known for his prolific printing activities, and Dri med indeed signs the illustrations of at least one work stemming from lHa btsun Rin chen rnam rgyal's efforts, that is the life and songs of rGod tshang pa mgon po rdo rje (Appendix text no. 10).

As may be seen, Dri med worked for royal commissions, for Chos dbang rgyal mtshan, and for the monk of royal birth lHa btsun Rin chen rnam rgyal, thus contributing to the finest blockprinted books produced in Mang yul Gung thang at the time. However, his work was not restricted only to book illustration, but he was in fact a full-fledged painter, as may be seen by his involvement with the renovation of the 'Phags pa lha khang. Hence, we may hopefully expect to find further mention, or even testimony, of his work, as one of the leading artists of the kingdom in the 16th century.

The images produced by the master Dri med at the peak of his career are readily recognizable. We may observe extreme richness in detail, especially in the depiction of the garments and implements of the figures; harmonious, elongated bodies; characteristic oval-shaped faces, with regular proportions, heart-shaped hairline, and the marks of the folds of the neck. But especially characteristic are the landscape elements which are depicted in the background of the main figures: peaked mountains with rivers streaming down (fig. 15.2 and 15.3), hard-cut rocks (figs 15.4, 15.5, 15.6), trees with big, carefully designed, leafs (fig. 15.4), or thick bushes with characteristically shaped trilobated leaves (fig. 15.5, 15.6). Clouds are depicted in two different shapes, both as stratus (horizontal, thin and filamentous, fig. 15.3), and cumulus (rounded and fluffy, with cauliflower-shaped outline, fig. 15.6). The sMan thang tradition became the predominant style of blockprinted books' illustrations in Mang yul

37 This is a reprint of the life story of Mar pa by gTsang smyon Heruka, realized in Mang yul Gung thang by a disciple of lHa btsun Rin chen rnam rgyal called gSung rab rgya mtsho; Sernesi 2011: 201-2.

38 This project is mentioned in lHa btsun chos kyi rgyal po'i rnam thar gyi smad cha (as in n. 40 below, fols. $4 \mathrm{a}-5 \mathrm{a}$ ), which also includes the dkar chags and smon lam of the enterprise (fols. 5a-9a): mkhas pa Dri med is also mentioned among the donors (ibid. fol. 6b). See also Ehrhard 2004: 84. For the master and his biography, see Clemente 2014. 
Gung thang during the first half of the 16th century. Besides mkhas pa Dri med, a number of other artists are explicitly associated with this painting tradition, i.e. rDo rje mgon po (who worked at the 1521 Mani bka' 'bum royal print with mkhas pa Dri med), dKon mchog rgyal po, ${ }^{39}$ and Don bzang. ${ }^{40}$ And also when the affiliation of the artist is not openly stated, or the work is anonymous, the Mang yul Gung thang regional style is easily recognizable by the details influenced by the sMan thang pa/Dri med tradition, in both the proportions and postures of the bodies, and the background elements that fill in the space of the illustration: among the most refined examples are the initial illustrations of the guidebook to the 'Phags pa Vati temple printed in 1532. The illustration on fol. 2 a (left) portrays the holy statue of Avalokiteśvara within the 'Phags pa lha khang temple - with its structure and roof clearly visible in the background flanked by the Tibetan kings of the imperial period Srong btsan sgam po and Khri srong lde btsan (fig. 15.7) ${ }^{41}$ Worthy of notice are also the illustrations of The Six secret songs of Mi la ras pa printed by lHa btsun Rin chen rnam rgyal at Brag dkar rta so in $155^{0}$ (fig. 15.8). ${ }^{42}$

39 Mentioned in the colophon of the sPrul sku rigs 'dzin mchog ldan mgon po'i rnam thar mgur 'bum dang ldan spro ba bskyed byed (NGMPP L 9/3 = L 189/4). The life and songs of the treasure discoverer Rig 'dzin mChog ldan mgon po (1497-1531) were printed in sKyid grong under the supervision of Chos dbang rgyal mtshan (= dGe slong chos [kyi] seng [ge]) in 1527. See Ehrhrard 2000: 32-33, 72-73; Colophon: le lha rang byon gsung 'byon ji bzhin pa/sman thang srol'dzin dkon mchog rgyal pos bkod.

He worked at the illustrations of at least two texts: (1) rNal 'byor dbang phyug lha btsun chos kyi rgyal po'i rnam thar gyi smad cha; NGMPP L 456/7, NGMPP E 2517/5, IsIAO Tucci collection no. 657(6); colophon (fol. 32a): sgos su par 'di' le lha'i ri mo pa//mkhas pa don bzang sman thang rgyud 'dzin mkhas. (2) Grub thob gtsang pa smyon pa'i rnam thar dad pa'i spu long g.yo ba; IsIAO Tucci collection no. 706; colophon: sgos su par 'di' le tha'i ri mo $\mathrm{pa} /$ /mkhas pa don bzang sman thang rgyud'dzin mkhas. For a description of the texts and an excerpt of the colophons, see Clemente 2007: 133-7.

'Phags mchog spyan ras gzigs dbang phyug va ti bzang po'i rnam thar nam mkha'i nor bu ma rig mun sel, NGMPP Reel L 686/6. For the traditions surrounding the statue and its temple, including a full transliteration of this text, see Ehrhard 2004, especially pp. 483521. For this print, and further images of the text, see Ehrhard forthcoming.

Mi la ras pa'i rdo rje mgur drug, IsIAO Tucci collection no. 1089(2). Another illustration from this volume, portraying Mi la ras pa, is found in Sernesi 2011, fig. 6, and may be compared with a drawing by Dri med in the 1540 print of the Mi la'i mgur 'bum (ibid., fig. 5). 


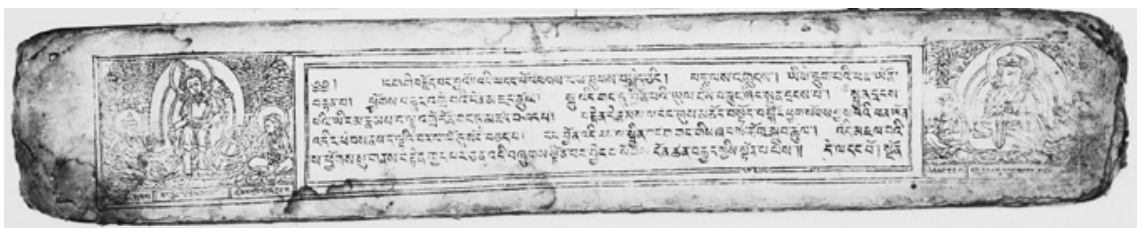

FIGURE 15.7 The Story of Va ti bzang po printed in 1532, fol. 2a. Kathmandu National Archives.

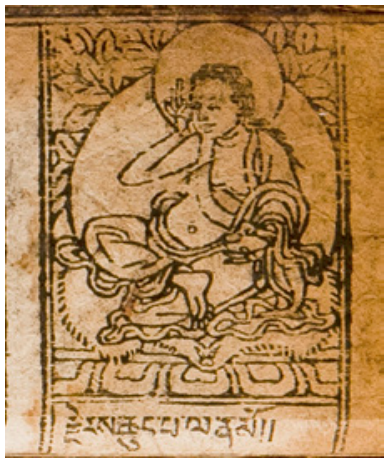

FIGURE 15.8

The Six Secret Songs printed in 1550, fol. 16 right. IsIAO

Tucci Collection.

As may be seen, it is possible to recognize a distinct style of woodcut book illustrations produced in Mang yul Gung thang by a determined group of artisans in the first half of the 16th century. Likewise, it may be possible to individuate specific workshops elsewhere in Central Tibet: although for these other regions the documentary evidence is still scarce, it is already possible to study 16th century book illustrations, and to trace the names of artisans working at multiple texts in a given area. Hence, to appreciate the distinctiveness of the Mang yul Gung thang regional style, we may compare it to a contemporary figurative tradition flourishing in the Central Tibetan region of dBus. Indeed, a volume printed in the fortress of Gong dkar in 1542 offers an example of book illustration likely belonging to the mKhyen ris tradition. However, differently from the case of mkhas pa Dri med, the images are not signed in the colophon of the text, nor is the adherence to a specific painting tradition explicitly claimed.

The master dGe bsnyen rNam par rgyal ba, known as mKhyen brtse, was a native of Gong dkar in dBus, and flourished around the 1460s, thus being a contemporary of sMan bla don grub. He was particularly linked, although not exclusively, to the Sa skya school, and his main patron (yon bdag), who was also 
his religious teacher, was the master Kun dga' rnam rgyal (1432-96). The latter entrusted to the artist the realization of most of the frescoes and the statues of the monastery of Gong dkar rDo rje gdan, founded in $1464-5 \cdot{ }^{43}$ His painting style was renowned for the execution of tantric deities, and it is said to be characterised by thicker colours and less expressive figures than the sMan ris. The tradition was long lasting, as masters painting in this fashion are recorded well into the 17 th century. ${ }^{44}$

The volume produced in the palace of Gong dkar in 1542 is a copy of the Jätakamālā by Âryaśüra supplemented by sixty-seven stories compiled by the 3rd Karma pa Rang 'byung rdo rje (1284-1339), which was realized upon the request of the Phag mo gru prince 'Gro ba'i mgon po (1508-1548). ${ }^{45}$ The craftsmen were headed by one rDo rje tshe dbang originary of gNyis in the nearby area of gNyal, who is also mentioned in colophons of works printed at Dwags la sgam po under the tenure of Dwags po bKra shis rnam rgyal $(1513-87) \cdot{ }^{46}$ The volume bears four illustrations on its opening pages (fig. 15.9), portraying the Buddha Śākyamuni (fol. 1b, top left), Nāgārjuna (fol. ıb, top right), Āryaśūra

43 See Jackson 1997: 254, 257. Accoding to Be-lo, mKhyen rtse also contributed to the murals at Yangs pa chen in 1506, although this could be late for the master himself; see ibid., 257. For the construction of the monastery of rDo rje gdan, and the work executed there by mKhyen brtse, see Fermer 2009: 132-5. For an overview of the site, and images of some of the relevant frescoes, see sKal bzang chos 'phel (ed.), Gong dkar chos sde'i gnas yig, Sam bho ța dben brgyud dpe tshogs, Gong dkar chos sde dgon, s.d..

44 See Jackson 1996: 139-61, Wangdu 2012. mKhyen ris artists are known to have worked upon the summon of the 5 th Dalai Lama and later by sDe srid Sang rgyas rgya mtsho; Jackson 1997: 257 .

45 NGMPP Reel L 528/2: Ston pa thams cad mkhyen pa'i skyes rabs phreng//bcu phrag gsum dang bzhi ni dpa' bo'i ste//phyi nas rang byung rdo rjes bdun lcag pai// drung bcus brgya rtsa rdzogs par mdzad pa bzhugs. Digital images of a copy are also included in Bod kyi shing spar lag rtsal gyi byung rim msdor bsdus, Bod ljongs bod yig dpe rnying dpe skrun khang, 2014, DVD 2, vol. no. 38. For the editorial history of this text, see Sernesi forthcoming. 'Gro ba'i mgon po (1508-1548) was the elder son of the Phag mo gru gong ma sde srid Ngag dbang bkra shis grags pa (1488-1563/4) and took residence in Gong dkar in 1524; Czaja 2013: 256, and n. 44. It may be noted that wall paintings in the 'Dus khang of Gong dkar rdo rje gdan monastery attributed to Mkhyen brtse depict a series of one-hundred previous lives of the Buddha, which are, however, said to be inspired by the dPag bsam gyi 'khri shing (Bodhisattvāvadānakalpalatā); see Gong dkar chos de'i gnasyig (as in n. 43), p. 25,81 .

46 These are the mNyam med dwags po'i chos bzhir grags pa'i gzhung gi'grel pa snying po gsal ba'i rgyan by La yag pa Byang chub dngos grub, and the gSang sngags rdo rje theg pa'i spyi don mdor bsdus pa legs bshad nor bu'i 'od zer by bKra shis rnam rgyal himself; Sernesi 2013: 199, 201. 

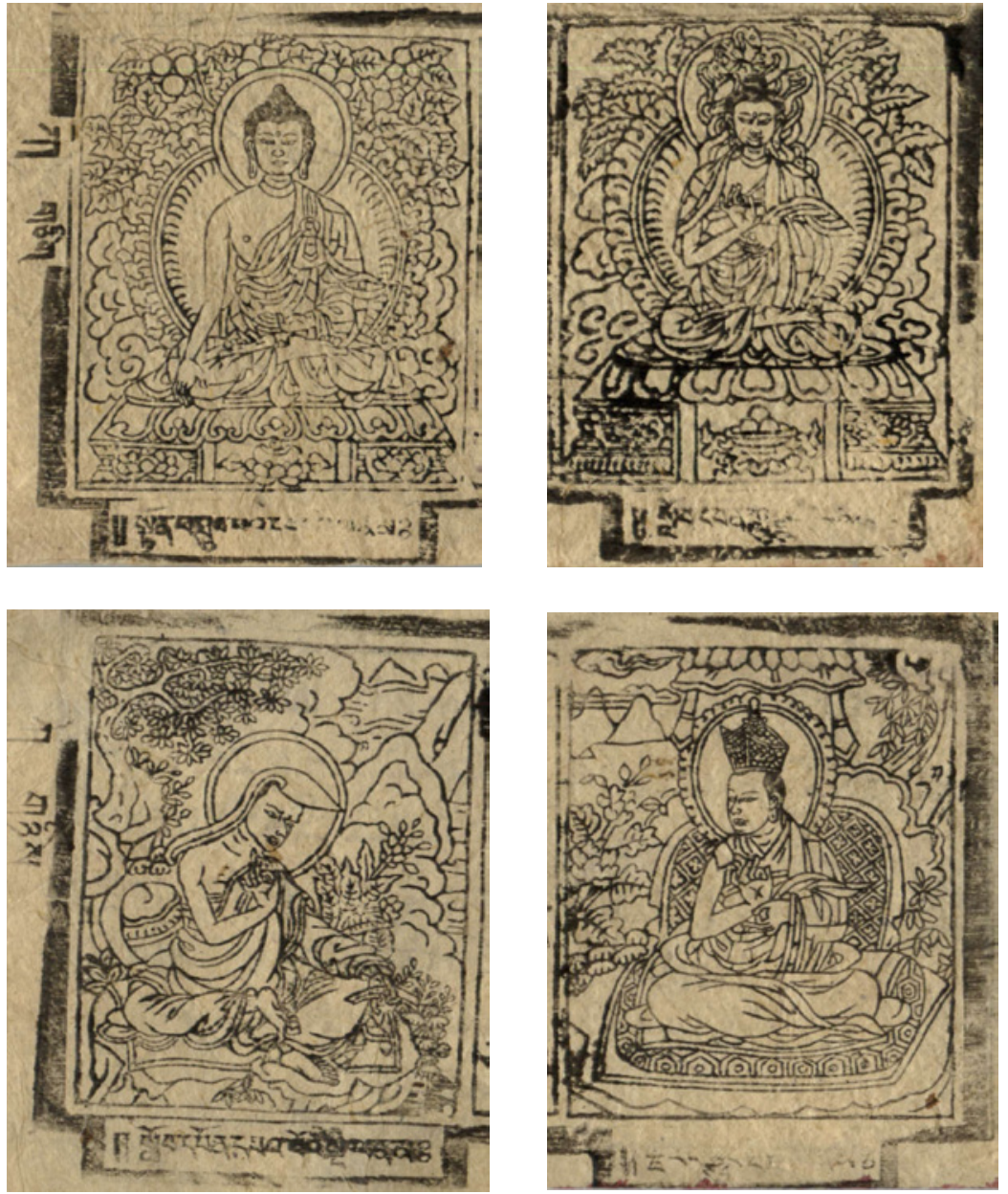

FIGURE 15.9 Illustrations of the Jātakamālā printed in Gong dkar in 1542. Paltsek Institute.

(fol. 2a, bottom left), and the 3rd Karma pa (fol. 2a, bottom right). The first two images are portrayed frontally, seated on a high lotus throne, surrounded by an elaborate halo; the background is filled with greenery of two different kinds, showing elongated fern-like leaves on the right illustration. The two masters are portrayed in three-quarters against a natural landscape. Āryaśūra wears an Indian monastic robe (samghāti i) that leaves the right shoulder bare, and holds a palm-leaf text in the left hand. He is seated on a mat upon a rock, besides a tree, amidst bushes and a large flower. A vase may be seen on his left side, under the tree. In the background a mountain is suggested behind thick clouds. Rang 'byung rdo rje is portrayed in his Tibetan monastic attire and wearing the 
black hat characteristic of his lineage. He sits among plants and flowers, and in the background clouds and mountains are also visible. His large throne, with a rounded wooden frame and a baldaquin, is akin to those portrayed in a series of thangkas of the 'Brug pa bKa' brgyud lineage painted in mKhyen ris style. ${ }^{47}$

We may compare this volume's illustrations with paintings of the mKhyen ris tradition, ${ }^{48}$ and with another roughly contemporary print from dBus, that is The Life of Ras chung pa, printed at Ras chung phug in the Yar lungs valley by rGod tshang ras chen (1482-1559) in 1531: its printing colophon mentions the prince 'Gro ba'i mgon po among the main donors. ${ }^{49}$ In so doing, we may detect distinctive details, which may be contrasted in turn with the Western Tibetan examples. First, the depiction of the halo: it is surrounded by flames, represented in a stylized and elaborate fashion (cf. the image of the Buddha Śākyamuni); also, radiant beams of light are portrayed as a string of small beads or petals surrounding the halo (like in the case of the 3rd Karma pa), or in its interior (like in the figure of the Buddha Saakyamuni). Second, the already mentioned characteristic throne of the 3rd Karma pa, with its large frame and decorated rear. Moreover, the lotus thrones of the deities show pointy, curly, ornate petals (cf. the image of the Buddha Saakyamuni), in contrast with the lotus petals of the Mang yul Gung thang depictions, which are usually rounded. And finally, the natural elements inserted in the background are also differently treated: while in the Western Tibetan examples bushes and trees are stylized, with respectively trilobated, and big oval leaves, in the images from Gong dkar the plants are more realistically depicted, with a great variety of types and shapes: in the portrait of Āryaśūra in the Gong dkar print for example, the leaves of the knotty tree are very small, and there are four different kinds of bushes and a flower. ${ }^{50}$ Also, the mountain tops and the thick rounded

47 Cf. Heller 2012, especially figs. 1, 2, and paintings IV (Mar pa), vi (sGam po pa), VII (Phag mo gru pa), XI (Chos rgyal Ngag dbang), XIII (bsTan 'dzin nor bu), XIV (unidentified).

48 As telling parallels, cf. especially the following pictures: (1) Buddha, mural from Gong dkar, 15th century, in Jackson 1996: 151 (pl. 19); (2) thangka of Amitāyus, in Jackson 1996: ${ }_{162-3}$ (pl. 78-9).

49 This volume is kept at the British Library, no. 19999d89. I thank Burkhard Quessel for providing me access to this text. This printing project was realized in a hare year, which must be 1531, as I discuss elsewhere. A more extensive analysis of 16th century prints from Gong dkar or dBus lies beyond the scope of this paper, and will be postponed to another occasion. I thank M. Fermer for showing me images from multiple such prints that he collected. For earlier prints realized at Gong dkar, see Jackson 1983: 8-16, and 1989: 10-7.

$5^{0}$ Note that Wangdu (2012) was able to count "as many as 65 different species and forms of leaves" depicted in the narrative series of the previous lives of the Buddha in the 'Dus khang of Gong dkar. 
clouds (behind Âryaśüra), as well as the thin filamentous clouds (behind the Karma pa), are sketchy and far from the conventional depictions adopted in the images from Mang yul Gung thang as shown above.

Therefore, we may see how printed texts constitute datable and localizable examples of artwork, which bear witness to the wider history of Tibetan art and material culture. Distinct regional styles may be recognized in book illustrations of the 16th century, and no doubt this investigation may be refined with the growing data that is becoming available. This endeavour may lead to the recognition of clues useful in determining the date and place of provenance of printed texts, and hence deserves attention from bibliographers and textual scholars alike. However, a note of caution is in order: stylistic features are not sufficient for this purpose, and should always be complemented with internal data, i.e. the information gathered from the book, such as details related in the colophon, names and place of origin of the artisans mentioned in the colophon or in the ming thangs, codicological features of the volume, references in the invocations and dedications to specific circumstances of production or transmission of the text, and so on. In turn, this must be corroborated by external data, such as information about the text's circulation and reception, or about its editorial history, passages in biographical sources relating the execution of a given printing project, identification of regional redactions of works, etc. ${ }^{51}$

$5^{1}$ On the comprehensive approach to the codex, see Scherrer-Schaub and Bonani 2002; for an attempt at such an enterprise, see Sernesi 2010; for relevant elements in the description of Tibetan printed books, see Clemente 2011. For a summary of this methodology in the context of the study of Medieval European manuscripts, see Segre Montel 2003: 492-3: "La miniatura si data in genere più facilmente della pittura monumentale, perché dal codice nel suo complesso si possono ricavare molte informazioni, complementari a quelle fornite dalla decorazione, che è solo un aspetto, tra i tanti, di quel manufatto complesso che è il libro scritto a mano. Trascurando anche solo uno di questi, si rischia di perdere dei dati essenziali: il calendario di un codice liturgico, per esempio, può indicarci, con la scelta dei santi elencati, la diocesi per la quale il manoscritto è stato eseguito, in alcuni casi la data di composizione, oppure il luogo dove in un determinato momento è stato utilizzato. Anche un testo o una sua redazione particolare possono orientarci verso una specifica regione o data, e il colophon (la sottoscrizione del copista), così come i versi o una miniatura di dedica possono rivelarci il nome del committente, del destinatario e magari del miniatore, mentre il solo esame della decorazione, per quanto approfondito e insostituibile per l'aspetto specifico dello stile, non riuscirebbe a fornirci altrettanti dati". 
Indeed, style may be misleading because artists would travel in order to be trained, and took pride in mastering multiple styles and combining them for the creation of their works. And during this period they were itinerant, at least in a regional setting, and if particularly famed could be called upon, or receive commissions, from afar. Even more importantly, books, as portable objects endowed with value and prestige, circulated widely, offered as gifts to honoured masters and generous donors, or sought-after for their doctrinal contents. Moreover, as I have discussed elsewhere, during the period in question cherished texts were often the object of multiple printed editions, to make them available at a different monastic centre or a far-away Tibetan region, to amend the existing edition when deemed unsatisfactory, or to substitute blocks worn out, damaged, or lost in fire and floods. In these cases, it was common practice to employ a pre-existing printed edition as the sample to prepare the new set of blocks, more or less directly. ${ }^{52}$ The illustrations would be copied too, and indeed very often we may readily recognize the prototype of a given edition also by looking at its iconographic program and at the composition of the individual illustrations, mirrored in the later print. In this way, the circulation of books favoured the circulation of stylistic trends and motives. Hence, it may be clear that the sole appraisal of the illustrations may not be sufficient and determinant in establishing the place and date of origin of a printed volume.

As a telling example it may suffice to finally look at a volume of the Jātakamālā reprinted in Mang yul Gung thang in 1574 (fig. 15.10). ${ }^{53}$ The Gong dkar ba edition may be clearly identified as the model on which the new edition is based, and indeed the subject and ordering of the illustrations follows closely the previous print: the initial folios bear, once again, images of the Buddha Śākyamuni (fol. ıb, left), Nāgārjuna (fol. ıb, right), Āryaśūra (fol. 2a, left), and the 3rd Karma pa (fol. 2a, right). Moreover, the debt may be recognized in the composition of the single illustrations, in the attire and posture of the figures, and even in the treatment of specific details, showing the characteristic mKhyen ris features: note in particular the decoration of the halo of

$5^{2}$ In the case called by Eimer 'technical identity', the previously printed text was glued to the blocks and used in place of the printing sheets (paryig) as the guideline for carving the new blocks. In the majority of cases the text was copied anew by a scribe, but following closely the printed sample; Sernesi forthcoming. See Sernesi 2015 for the $b K a^{\prime}$ gdams glegs bam example.

53 NGMPP L 568/9-569/1: Ston pa thams cad mkhyen pa'i skyes rabs phreng//bcu phrag gsum dang bzhi ni dpa' bo'i ste/ /phyi nas rang byung rdo rjes bdun lcag pai// drung bcus brgya rtsa rdzogs par mdzad pa bzhugs. On this printed edition, produced by Byams pa phun tshogs (1503-81), see Ehrhard 2012: 166; Sernesi forthcoming. 


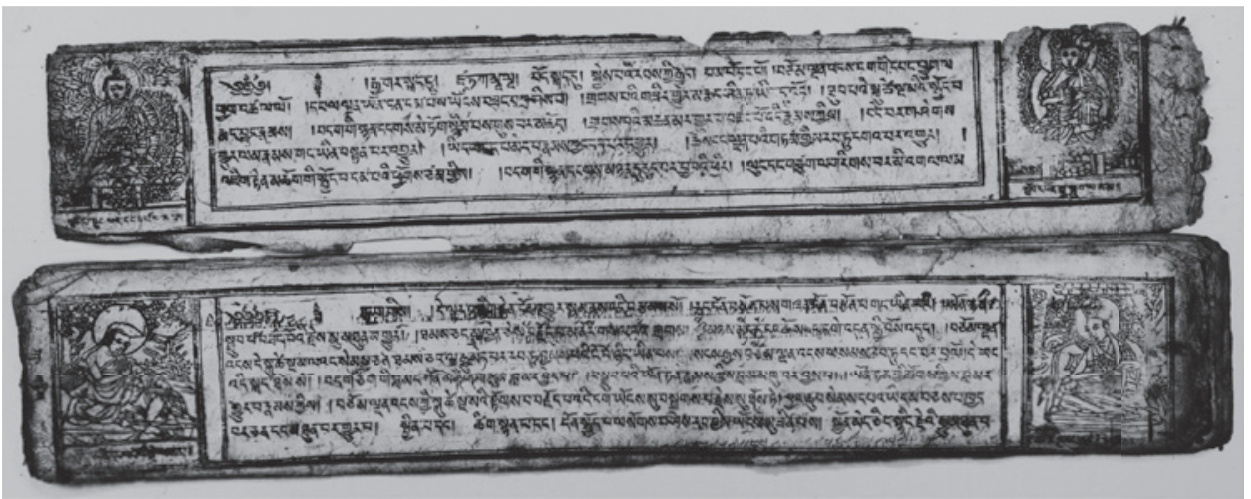

F IG URE 15.10 Jātakamālā, printed Mangyul Gung thang in 1574. Kathmandu National Archives.

the Buddha figure, the greenery behind it, the tree in the background of the portrait of Āryaśūra, and the throne of the Karma pa, with its rounded wooden frame and baldaquin. On the other hand, to the left of Āryaśūra is depicted a waterfall in the expected manner (cf. fig. 15.2 and 15.3), replacing the clouds and mountains of the original picture. In this case, a purely stylistic analysis would be confusing and could lead to mistaken conclusions, if not supported by research into the editorial history of the volume in question.

Therefore, I am arguing for an approach to the codex in its integrity, which brings together the study of its formal features and of its textual contents. This entails the investigation of the circumstances in which it was produced, including not only the identification of the writers, the recipients, and the sponsors, but also the understanding of the technical knowledge involved in its manufacture, the composition of the workshops, and the organisation of labour. The figure of $m k$ has pa Dri med offers an enlightening point of view on these practices, and I hope thereby to have shown how book illustrations and illustrators deserve much more attention than they have received so far.

\section{Appendix: The Works}

1. 1521. Mani bka' 'bum. NGMPP Reel E 2933/5-2935/1. Cambridge University Library, Tibetan 149. Royal Print, realized in rDzong dkar under the supervision of 'Jigs med bzang po, Chos dbang rgyal mtshan, and Chos skyong rdo rje.

The scribes are brgya dpon Chos skyong rdo rje and mkhas pa 'Phags skyabs. The blocks were carved by seven carvers headed by dge slong Seng ge and drung yig dPal ldan rgyal po. The artists are rDo rje mgon po and Dri med. The illustrations 
were carved by brkos byed pa mkhas pa Chos skyabs dpal bzang, bzo rig mthar phyin bSod rnams rnam rgyal, and mkhas pa Skyabs pa. Ehrhard 2013, especially pp. 154-5; Colophon Appendix I.6, p. 167 (fol. 369b-370a): le lha rang byung gsung 'byon 'dra ba 'di//sman thang mkhas pa'i rgyud'dzin gung thang pa//mkhas pa rdor mgon dri med la sogs kyis/ /skal bzang 'dren byed bdud rtsi'i gru char phab: "The chapter-deities, like selfarisen, self-talking [images], descend as a drizzle of ambrosia conveying good fortune, by [the skill of] the artists rDo rje mgon po, Dri med, etc. from Gung thang, who follow the tradition of the artist from sMan thang."

Illustrations:

Vol. KA: lb (l) Ston pa sangs rgyas, rGyal ba 'Od dpag med, Byams mgon; (r) Sras nor bu 'dzin pa, 'Jig rten dbang phyug, Yi ge drug ma.

2a (l) Bal mo Khri btsun, Chos rgyal Srong btsan rgam po, rGya mo Kong jo; (r) lHa lcam Man dha ra, U rgyan Padma 'byung gnas, Ye shes mtsho rgyal.

217a (l) Slob dpon Grub thob dngos grub; (r) mNga' bdag Nyang ral chen po.

218b (l) Bla ma Mi skyod rdo rje; (r) rJe btsun Shākya bzang po.

323 b (l) Bla ma lHa rje dag pa 'bum; (r) lCam mo Ye shes mchog ma.

324a (l) Grub thob Chu sgom zhig po; (r) mTha' bzhi bya bral chen po.

Vol. KHA: 1b (l) 'Jam dbyangs bsod nams seng ge; (r) Bla ma bKra shis rgyal mtshan. 2a (l) dBus pa Blo gros rgyal mtshan; (r) 'Phags mchog Nor bu bzang po.

$319 \mathrm{~b}$ (l) Chos rje Bzang po rgyal mtshan; (r) mKhas grub dPal ldan sangs rgyas.

$320 b$ (l) mKhas btsun bSam grub dpal; (r) mKhas grub Chos kyi legs pa.

$370 b$ (l) rJe rab 'byams pa Nor bu phun tshogs (r) rJe Kun dga' rgyal mtshan.

$371 a$ (l) rDo rje nag po chen pos bgegs rnams 'joms; (r) rNam thos bu yis 'dod dgu char ltar'bebs.

2. 1521. Nyams yig mani lu gu rgyud. NGMPP Reel L 61/21-62/1, facsimile Ehrhard 200oc. Printed at rDzong dkar by bla ma 'Jigs med bzang po.

Chos dbang rgyal mtshan acts as carver, with bShes gnyen Kun ne and bSod rnams rnam rgyal. The scribe is Chos skyong rdo rje. Ehrhard 2000: 71; Colophon no. 3, p. 87 (fol. 36b-37a): le lha rang byung mtshan dpe'i dpal 'bar 'di/ mkhas pa dri med dad pa'i mtsho las 'khrungs: "the glowing splendour of the chapter-deities, bearing the marks of self-arisen [images], is born from the ocean of faith of the master Dri med."

Illustrations:

lb (l) [bTsun pa] Chos legs; (r) Bram ze chen po.

37a (l) mGon po Klu sgrub; (r) Yang dgon chos rje.

3. 1524. rGyal ba yang dgon chos rje'i mgur 'bum and rGyal ba yang dgon chos rje'i bka' 'bum yid bzhin nor bu. NGMPP Reel L 66/2-66/3, IsIAO Tucci Collection no. 286/1286/2. Collected Songs and Collected Saying of Yang dgon pa rGyal mtshan dpal bzang po (1213-58), printed at Kun gsal gang po che. 
The scribe is 'Phags skyabs; the carvers include Chos dbang rgyal mtshan and bSod nams bkra shis. Ehrhard 2000: Col. no. 4, p. 91: le lha rang byung gsung byon 'dra ba 'di) gung thang mkhas pa dri med dad pas bzhengs: "The chapter-deities, like self-arisen, self-talking [images], were crafted with faith by mkhas pa Dri med from Gung thang".

Illustrations:

mGur 'bum: 1b (l) rGyal ba Yang dgon chos rje; (r) mTshan ldan Rin po che Chos legs. 65 a (l) rGyal ba Yang dgon pa; (r) mNga' bdag Chos legs.

bKa' 'bum: 1b (l) mKhas btsun chos skyi rgyal po sPyan snga ba; (r) Ko brag pa. 128a (l) sKu gsum bde chen rgyal ba rGod tshang pa; (r) Pạ chen Sa skya pa.

4. 1533. Theg mchog mdzod. Berlin State Library Hs. Or. 1648. NGmpP Reel AT 53/1754/1. Facsimile Ehrhard 20oob. Printed at Kun gsal sGang po che.

The scribe of the first part is gTsang pa 'Od zer, of the latter part dGe slong and sGrol ma. The carvers were fourteen. The images at the beginning of the volume were carved by bSod nams bkra shis. Ehrhard 2000: 38, 73-4, Colophon n. 8, especially pp. 111-2; Everding 2015, s.v. Hs. Or. 1648. Images in Jackson 1996: 123-5. Colophon (fol. 508b): le Iha'i ri mo sprul sku sman thang pa'i/ brgyud 'dzin mkhas pa'i 'byung gnas gung thang pa/ mkhas pa dri med sor mo'i sgyu rtsal lo: "the drawings for the images [were made by] the skilled fingers of $m k h a s$ pa Dri med, the artist originary of Gung thang who follows the tradition of sprul sku sMan thang pa".

Illustrations:

ib (l) Longs sku rNam snang, Chos sku Kun bzang yab yum, sPrul sku rDo rje 'chang; (r) Slob dpon 'Jam dpal bshes gnyen, Rig 'dzin dGa' rab rdo rje, Śrī Siṃha.

2a (l) Rig 'dzin dznya na sutra, Rig 'dzin Bi ma la mi tra; (r) U rgyan Pad ma 'byung gnas, Chos rgyal Khri srong lde btsan.

509b (l) gNas brtan lDang ma lhun rgyal, Nyang Ting nge 'dzin bzang po; (r) lCe btsun Seng ge dbang phyug, rGyal ba Zhang ston.

$510 a$ (l) Klong chen Rab 'byams pa, Chos 'di'i rTsa ba'i bla ma; (r) bKa' bsrungs E ka tsa ti, rGyal chen rNam thos sras.

5. 1534-5. The Life and songs of sPrul sku Nam mkha' rgyal mtshan, printed at the request of sKyid gshongs pa Chos kyi grags pa. Only volume Kha (i.e. the rnam thar) is extant: dPal ldan bla ma dam pa sprul pa'i skyes mchog nam mkha' rgyal mtshan dpal bzang po'i rnam par thar pa skal ldan dga' ba bskyed pa'i pad dkar yid kyi 'dod 'jo, Collection University of Hamburg.

The scribe is Thugs rje skyabs pa from sNyings. Ehrhard 2000: 39; Ehrhard forthcoming. Colophon (fol. $57 \mathrm{~b}$ ): le lha'i rig byed mkhas pa dri med do: "the artist who drew the illustrations is Dri med".

Illustrations (vol. Kha):

ib (l) sKyes mchog 'Ba' ra ba; (r) sPrul sku Nam mkha' rgyal mtshan.

58a (l) Ye shes mgon po phyag bzhi pa; (r) bKra shis tshe rings ma. 
6. 1537. sPrul sku bstan gnyis gling pa pad ma tshe dbang rgyal po'i rnam thar yid bzhin nor bu, and sPrul sku bstan gnyis gling pa pad ma tshe dbang rgyal po'i mgur 'bum dgos 'dod kun 'byung. NGMPP Reel L 143/5, L 143/6-144/1. The Life and Collected Songs of bsTan gnyis gling pa. Realized at the palace Khyung rdzong dkar po with royal sponsorship, and under the supervision of Chos dbag rgyal mtshan.

The scribes were bSod nams 'od zer from gTsang, and Thugs rje skyabs pa from sNyings. Ten carvers worked at the project, and the images were carved by bSod nams bkra shis. Ehrhrad 2000: 40-1, 74; Colophon 9, pp. 115-7. Colophon (fol. 186b): le lha'i rnam 'gyur sprul sku sman thang pa'i/ brgyud'dzin mkhas pa dri ma mes pas bkod/ (...) le lha'i rkos byed bsod nams bkra shis so: "the appearance of the illustrations was determined by mkhas pa Dri ma med pa, who follows the tradition of sprul sku sMan thang pa".

Illustrations:

rNam thar: $1 \mathrm{~b}(\mathrm{l})$ Chos sku Kun bzang yab yum; (r) Longs s[ku] [...]

mGur 'bum: 1 b (l) Bram ze chen po Sa ra ha; (r) lHa btsun [...] rab brtan.

2a (l) [...] mChog ldan mgon po: (r) Rigs 'dzin Pad ma tshe dbang rgyal po.

187a (l) mGon po Tshe dpag med (r) rNam sras mdung dmar can.

7. 1539. bKa' gdams glegs 'bam. This edition has been reproduced in the Sata Pitaka Series vols. 309-310 (New Delhi 1982). Several incomplete copies exist: cf. NG MPP Reel L 587/1 (vol. Ka, fols. 124-365), NGMPP Reel L 784/2 (vol. Ka, fols. 247-365), NGMPP Reel L 784/3 (vol. Kha, fols. 1-278; continues in Reel L 785/1, not seen); TвRC W4CZ1021 (vol. Kha, fols. 1-343), British Library 19999 d107 (vol. Ka): I thank B. Quessel for assistance in getting access to the latter. Cf. also dPal brtsegs bod yig dpe rnying zhib 'jug khang, Bod kyi shing spar lag rtsal gyi byung rim mdor bsdus, Bod ljongs bod yig dpe rnying dpe skrun khang, 2013, DVD 1, no. 20.

The illustrations were drawn by mkhas pa Dri med, mkhas pa Chos dpal, and mkhas pa sMon lam; those of the first volume were carved by mkhas pa chen po bSod nams bkra shis. Twenty three carvers worked at the text, including bSod nams bkra shis. Several scribes contributed, including dGe slong sgrol ma seng ge, dpon yig Rin chen, and dpon yig Thugs rje skyabs pa: the latter, in particular, wrote the first volume. Ehrhard 2000: 19 n. 17, 42-43, 74-75; Colophon 10, pp. 118-29. See also Eimer 1984; Jackson 1996: 121; Sernesi 2015. Colophon (fol. 341b): le lha'i dpe ris mangyul gung thang pa/mkhas pa dri med mkhas pa chos dpal dang/mkhas pa smon lam sogs kyis gzabs nas bris: "the template drawings for the illustrations were drawn with zeal by [the artists] from Mang yul Gung thang mkhas pa Dri med, mkhas pa Chos dpal, mkhas pa sMon lam, and so forth.

Illustrations:

vol. KA. 1b (l) Ti lo pa, rDo rje 'chang, Nā ro pa; (r) Byams pa, Shākya'i rgyal po, 'Jam dbyangs.

2a (l) Thogs med, dPal mgon Klu sgrub, dPal mchog Dom bhi pa; (r) Mi g.yo pa, Thugs rje chen po, sGrol ma. 
19a (l) Jo bo rje dPal ldan A dhi sha [=Atiśa]; (r) 'Brom ston pa rgyal ba'i 'byung gnas. $20 b$ (l) rNgog legs pa'i shes rab; (r) mNga' ris pa Shes rab rgyal mtshan.

119a (l) Phu chung pa gZhon nu rgyal mtshan; (r) Zhang ka ma pa Rin chen rgyal mtshan.

124b (l) Stab ka pa Dar ma rgyal mtshan; (r) Stab ka pa Byang chub bzang po.

125a (l) Stab ka pa rNam mkha' rin chen; 'Brom ston sprul pa gZhon nu blo gros.

246a (l) Mkhan chen Nyi ma rgyal mtshan; (r) Rin chen gling pa Rin chen byang chub.

247b (l) gSer gling pa Chos kyi grags pa, Bla ma A wa dhu ti pa; (r) Bla ma Byang chub bzang po, Dze ta ri dGra las rnam rgyal.

248a (l) Jo bo chen po rJe dpal ldan A ti sha; (r) 'Brom ston rgyal ba'i 'byung gnas.

365a (l) Yi dam Thugs rje chen po; (r) rJe btsun sGrol ma dkar mo.

vol. KH A. ib (l) Nag tsho tshul rgyal, Jo bo rje, Khu ston brTson 'grus g.yung drung; (r) sPyan snga ba, 'Brom ston, Pu to ba rin chen.

2a (l) dGa' lung pa rigs gi bDag po'i dpal, dGa' lung pa Byang chub dpal; (r) Bla ma dam pa bSod nams 'od zer, Go sngon chu ser ba Sangs rgyas bzang po.

2b (l) Bla ma dPal ldan pa; (r) mKhas mchog bSod nams bzang po.

214a (l) sTag tshang chos 'khor ba bSod nams 'od zer; ( $r$ ) sBa tshab sga gdong pa [=Pa tshab dga' gdong pa] Ye shes tshul khrims.

215b (l) mKhan chen Ratnākaraśānti; (r) Rin po che Kun dga' blo gros.

216a (l) mKhan chen Legs pa rin chen; (r) Rtsa ba bla ma Kun dga' legs pa bkra shis.

342a (l) Chos rje Sa skya Pandita; (r) Chos rje Blo bzang grags pa.

342b (l) Dhar ma sa dhu [bTsun pa Chos legs], U rgyan Padma 'byung gnas, rJe Ra tna dhā dza [dKon mchon rgyal mtshan]; (r) rJe Śrī man Udaya [Dpal ldan dar], rJe bstun A bha ya ki rti [Bo dong Jigs med grags pa], rJe Ki rti dznyā na [Grags pa ye shes].

343a (l) sGrol ma dkar mo, mGon po Tshe dpag med, lHa mo Nor rgyun ma; (r) bKa' bsrung Kṣetrapāla, mGon po Phyag bzhi pa, 'Jigs byed chen po.

8. 1540. The Collected Songs of Mi la ras pa by gTsang smyon Heruka. Wellcome Tibetan 6, Wellcome Tibetan 64; Chicago Field Museum, B. Laufer Collection FM 206 (Catalogue. no. 4125.336333). Printed in Lan 'de[/dhe] glang phug under the direction of rNal 'byor dbang phyug Chos kyi rgya mtsho.

The scribe is gTsang pa 'od zer. The images were carved by dpon btsun Pad ma. Eimer 1996; Sernesi 2011: 191-7, Colophon 1b, pp. 220-5. Colophon (fol. 443b): le lha'i rig byed gsung 'byon 'dra ba 'di/ /mkhas pa'i mchog gyur dri med mgon pos he: "The [artist] who drew the chapter-deities, like self-talking [images], is the supreme artist Dri med mgon po."

Illustrations:

lb (l) Mi la ras pa,; (r) Dwags po lha rje(?).

2a (l) Ras chung pa, (r) [...]. 
263b (l) Ston pa bo dhi rā dza (r) rJe btsun Sha ra rab 'byams pa.

264a (l) Grub thob gTsang smyon pa; (r) bKra shis tshe rings ma.

9. 1545. The Life and the Songs of sPrul sku Nam mkha' rgyal mtshan (1475-1530). Printed in the Lan 'de[/dhe] valley. dPal ldan bla ma dam pa sprul sku nam mkha' rgyal mtshan dpal bzang po'i rnam par thar pa dgos 'dod kun 'byung nor bu'i 'phreng ba (NG MPP Reel L 18/14), and Śākya dge slong nam mkha' rgyal mtshan dpal bzang po'i mgur 'bum: the mgur 'bum has been reproduced in Rare dKar brgyud pa Texts from Himachal Pradesh. A collection of biographical works and philosophical treatises. Reproduced from prints from ancient western Tibetan blocks by Urgyan Dorje, New Delhi, 1976, pp. 181-271.

These works were realized by the scribe gTsang pa bSod nams 'od zer, and by five carvers from the region of gTsang, including three which had worked at the $1540 \mathrm{Mi}$ la'i mgur 'bum woodblocks: mkhas pa mGon po rgyal mtshan, dpon btsun Pad ma and bcu dpon rDo rje rgyal mtshan. The latter carved the images drawn by mkhas pa Dri med. On the printing of these two works, marked volumes Ka and Kha respectively, see Ehrhard 2000: 64, 76, and Col. no. 12 (pp. 142-7), which applies to both.

Illustrations:

Vol. Ka: 1b (l) rGyal ba rdo rje 'chang rgyal po; (r) Bram ze chen po Sa ra ha. 2a (l) Bla ma Zhang g.yu brag pa; (r) rGyal ba Yang dgon chos rje.

48a(l) sKyes mchog 'bar[='ba'] ra ba; (l) [...]

Vol. Kha: 1 b (l) Mi la ras pa; (r) Dwags po bSod nams [rin chen]. 2a (l) mKhas btsun Nam mkha' rgyal mtshan; (r) Thugs sras Nam mkha' rdo rje.

46a (l) dPal Ye shes mgon po; (r) Chos bdag bKra shis tshe rings ma.

10. $1563(?)$. rJe rgod tshang pa'i rnam thar rgyal thang pa bde chen rdo rjes mdzad pa la mgur chen 'gas rgyan pa. NGMPP Reel L 211/3, 969/5-970/1, E 2518/8. The life and songs of rGod tshang pa mgon po rdo rje. Printed by lHa btsun Rin chen rnam rgyal $\left(1473^{-1557)}\right.$ at Brag dkar rta so in a water pig year (chu mo phag gi lo), which, however, is difficult to accept considering the life span of the master.

Colophon.: le lha tshugs legs mkhas pa dri med pa: "The well-shaped images [were drawn by] mkhas pa Dri med pa".

Illustrations:

lb (l) rJe rGod tshang pa; (r) Grub thob gtsang pa.

\section{Bibliography}

Armstrong, L. 1991. The Impact of Printing on Miniaturists in Venice after 1469. In Printing the Written Word. The Social History of Books, circa 1450-1520, ed. S. Hindman, 174-202. Ithaca and London: Cornell University Press. 
Bacot, J. 1954. Titre et colophons d'ouvrages non canoniques tibétains. Textes et traduction. Bulletin de l'école Française d'Extrême-Orient 44/2: 275-337.

Bühler, C. F. 196o. The Fifteenth-Century Book. The Scribes. The Printers. The Decorators. Philadelphia: University of Pennsilvania Press.

Cabezón, J. I. 2001. Authorship and Literary Production in Classical Buddhist Tibet. In Changing Minds. Contributions to the Study of Buddhism and Tibet in Honor of Jeffrey Hopkins, ed. G. Newland, 233-63. Ithaca: Snow Lion.

Caumanns, V. 2013. Pạ̣ chen Shākya mchog ldan's Monastic Seat Thub bstan gSer mdog can (Part I): The History of its Foundation. In Nepalica-Tibetica: Festgabe for Christoph Cüppers, eds. F.-K. Ehrhard and P. Maurer, vol. 1, 65-88. Andiast: International Institute for Tibetan and Buddhist Studies.

Chartier, R. 2007. The Printing Revolution. A Reappraisal. In Agent of Change. Print Culture Studies after Elizabeth L. Eisenstein, eds. S. A. Baron, E. N. Lindquist, E. F. Shevlin, 397-408. Amherst and Boston: University of Massachusetts Press.

Clemente, M. 2007. Colophons as Sources: Historical Information from some Brag dkar rta so Xylographies. Rivista di Studi Sudasiatici 2: 121-58.

- 2011. From Manuscript to Block Printing: in the Search of Stylistic Models for the Identification of Tibetan Xylographs. Rivista di Studi Orientali 84/1-4: 51-66.

- 2014. Shedding Some Light upon lHa btsun Rin chen mam rgyal (1473-1557): A Study of Two Untranslated Works from the Tucci Tibetan Collection. In From Mediterranean to Himalaya - A Festschrift to Commemorate the 120th Birthday of the Italian Tibetologist Giuseppe Tucci. Beijing: China Tibetology Publishing House, pp. 435-502.

Cüppers, C. 2010. Some Remarks on Bka' 'gyur Production in 17th-century Tibet. In Edition, éditions. L'écrit au Tibet, évolution et devenir, eds. A. Chayet, C. ScherrerSchaub, F. Robin, J.-L. Achard, 115-128. München: Indus Verlag.

Cüppers, C., L. van der Kuijp, U. Pagel. 2012. Handbook of Tibetan Iconometry. A Guide to the Arts of the 17th Century. Leiden: Brill.

Czaja, O. 2013. Medieval Rule in Tibet. The Rlangs Clan and the Political and Religious History of the Ruling House of Phag mo gru pa. Wien: Verlag der Österreichischen Akademie der Wissenschaften.

De Rossi Filibeck, E. 2002. Una nota sulle immagini decorative delle xilografie tibetane. In Oriente e Occidente. Convegno in ricordo di Mario Bussagli: Roma 31 maggio-r giugno 1999, eds. C. Silvi Antonini, B. M. Alfieri, A. Santoro, 92-103. Pisa-Roma: Istituti Editoriali e Poligrafici Internazionali.

Diemberger, H. 2012. Quand le livre devient relique. Les textes tibétains entre culture bouddhique et transformations technologiques. Terrain 59: 18-39.

Donati, L. 1978. Le iniziali stampate a mano. Gutenberg-Jahrbuch 15: 37-42.

Drège, J.-P. 1991. La lecture et l'écriture en Chine et la xylographie. Études chinoises 10/1-2: 77-111. 
1999. Du texte à l'image: les manuscrits illustrés. In Images de Dunhuang. Dessins et peintures sur papier des fonds Pelliot et Stein, 105-67. Paris: EPHEO.

Ehrhard, F.-K. 2000. Early Buddhist Block Prints from Mang-yul Gung-thang. Lumbini: Lumbini International Research Institute.

- 200ob. The Oldest Block Print of Klong-chen Rab-'byams-pa's Theg mchog mdzod. Lumbini: Lumbini International Research Institute.

_. 200oc. Four Unknown Mahāmudrā Works of the Bo-dong-pa School. Lumbini: Lumbini International Research Institute.

- 2oood. The Transmission of the dMar-khrid Tshem-bu lugs and the Mani bka' 'bum. In Vividharatnakaraṇdaka: Festgabe für Adelheid Mette, 199-215. Swisttal-Odendorf.

- 2004. Die Statue und der Tempel des Ārya Va-ti bzang-po. Wiesbaden: Ludwig Reichert Verlag.

. 2012. Gnas Rab 'byams pa Byams pa phun tshogs $\left(15^{03}-15^{81}\right)$ and his Contribution to Buddhist Block Printing in Tibet. In This World and the Next: Contributions on Tibetan Religion, Science and Society, 149-176. Andiast:International Institute for Tibetan and Buddhist Studies.

- 2013. The Royal Print of the Mani bka' 'bum: Its Catalogue and Colophon. In Nepalica-Tibetica: Festgabe for Christoph Cüppers, eds. F.-K. Ehrhard and P. Maurer, vol. 1, 143-172. Andiast: International Institute for Tibetan and Buddhist Studies. forthcoming. Buddhist Hagiographies from the Borderlands: Further Prints from Mang-yul Gung-thang. In Proceedings of the Conference Manuscript and Xylograph Traditions in the Tibetan Cultural Sphere: Regional and Periodical Characteristics, ed. O. Almogi.

Eimer, H. 1984. Zur Faksimile-Ausgabe eines alten Blockdruckes des bKa' gdams glegs bam. Indo-Iranian Journal 27: 45-7.

- 1996. Two Blockprint Fragments of Mi la ras pa's Mgur 'bum Kept in the Wellcome Institute, London. Zentralasiatische Studien 26: 7-20.

Everding, K.-H. 2015. Tibetische Handschriften und Blockdrucke, Teil 18. Prachthandschriften, alte Blockdrucke und eine Dhärañi-Sammlung. Bestand der Orientabteilung, Staatsbibliothek zu Berlin - Preussischer Kulturbesitz. Stuttgart: Franz Steiner Verlag. Fermer, M. 2009. The Life and Works of Gong dkar rDo rje gdan pa Kun dga' rnam rgyal (1432-1496). MA Thesis, University of Hamburg.

Ferrari, A. 1958. mK'yen brtse's Guide to the Holy Places of Central Tibet. Roma: Istituto Italiano per il Medio ed Estremo Oriente.

Grönbold, G. 1991. Tibetische Buchdeckel. München: Bayerische Staatsbibliothek. 2002. Glegs shing, The Art of Tibetan Book Covers. The Tibet Journal 27/3-4: $171-82$. 
Heller, A. 2012. Fourteen Thangkas of the 'Brug pa bKa' brgyud pa. In The Arts of Tibetan Painting. Recent Research on Manuscripts, Murals and Thangkas of Tibet, the Himalayas and Mongolia (11th-19th century). PIATS 2010: Proceedings of the Twelfth Seminar of the IATS Vancouver, 2010, ed. A. Heller. http://asianart.com/articles/ heller4.

Hind, A. M. 1935. An Introduction to a History of Woodcut with a Detailed Survey of the Work Done in the Fifteenth Century. London: Constable and Company Ltd.

Hirsch, R. 1978. Title Pages in French incunables, 1486-1500. Gutenberg-Jahrbuch 15: $63-6$.

Imaeda, Y. 1977. Mise au point concernant les éditions chinoises du Kanjur et du Tanjur tibétains. In Essais sur l'art du Tibet, eds. A. W. MacDonald and Y. Imaeda, 23-51. Paris: Librairie d'Amerique et d'Orient.

Jackson, D. 1983. Notes on Two Early Printed Editions of Sa-skya-pa Works. The Tibet Journal 8/2: -24 .

- 1989. More on the Old dGa'-ldan and Gong-dkar-ba Xylographic Editions. Studies in Central and East Asian Religions 2:1-18.

- 1996. A History of Tibetan Painting. Wien: Verlag der Österreichischen Akademie der Wissenschaften.

- 1997. Chronological Notes on the Founding Masters of Tibetan Painting Traditions. In Tibetan Art. Towards a Definition of Style, eds. J. Casey Singer and P. Denwood, 254-61. London: Laurence King.

Jest, C. 1961. A Technical Note on the Tibetan Method for Block-Carving. Man 61: 83-5. Karmay, H. 1975. Early Sino-Tibetan art. Warminster: Aris and Phillips.

Klimburg-Salter, D. 1990. The Gilgit Manuscript Covers and the Cult of the Book. In South Asian Archaeology 1987. Proceedings of the International Conference of the Association of South Asian Archaeologists in Western Europe, eds. M. Taddei and P. Callieri, 815-30. Roma: Istituto per il Medio ed Estremo Oriente.

Kuijp, van der, L. 1983. Contributions to the Development of Tibetan Buddhist Epistemology. From the eleventh to the thirteenth century. Wiesbaden: Franz Steiner Verlag. Labarre, A. 1982. Les incunables: la présentation du livre. In Histoire de l'édition française. Le livre conquérant. Du Moyen Âge au milieu du XVII ${ }^{e}$ siècle, eds. R. Chartier and H.-J. Martin, 228-55. Promodis [now: Fayard/Promodis, 1989].

Lo Bue, E. 1992. The Princes of Gyantse and Their Role as Builders and Patrons of Arts. In Tibetan Studies, Proceedings of the 5th Seminar of the International Association for Tibetan Studies, Narita 1989, eds. S. Ihara and Z. Yamaguchi, vol. 2, 559-73. Narita: Naritasan Shinshoji.

McKitterick, D. 2003. Print, Manuscript and the Search for Order, 1450-1830. Cambridge University Press.

Ricca, F. 1997. Stylistic Features of the Pelkhor Chöde at Gyantse. In Tibetan Art. Towards a Definition of Style, eds. J. Casey Singer and P. Denwood, 196-209. London: Laurence King. 
Ricca, F. and E. Lo Bue 1993. The Great Stupa of Gyantse, A Complete Tibetan Pantheon of the Fifteenth Century. London: Serindia Publications.

Scherrer-Schaub, C. and G. Bonani. 2002. Establishing a typology of the old Tibetan manuscripts: a multidisciplinary approach. In Dunhuang Manuscript Forgeries, ed. S. Whitfield, 184-215. London: The British Library.

von Schroeder, U. 2006. Empowered Masters: Tibetan Wall Paintings of Mahāsiddhas at Gyantse. London: Serindia Publications.

Segre Montel, C. 2003. Miniatura. In Arti e storia nel Medioevo. Volume secondo. Del Costruire: tecniche, artisti, artigiani, committenti, eds. E. Castelnuovo and G. Sergi, 491-505. Torino: Giulio Einaudi editore.

Selig-Brown, K. H. 2012. Protecting Wisdom: Tibetan Book Covers from the MacLean Collection. New York: Prestel.

Sernesi, M.2010. AManual on Nāropa's Six Yogas by sPyan snga Nyer gnyis pa(1386-1434): Tucci Tibetan Collection 1359. Indo-Iranian Journal 53: 121-63.

- 2011. A Continuous Stream of Merit: The Early Reprints of gTsang smyon Heruka's Hagiographical Works. Zentral-asiatische Studien 40: 179-237.

- 2013. Rare Prints of bKa' brgyud Texts: A Preliminary Report. In NepalicaTibetica: Festgabe for Christoph Cüppers, eds. F.-K. Ehrhard and P. Maurer, vol. 2, 191-210. Andiast: International Institute for Tibetan and Buddhist Studies.

- 2015. Bibliography and Cultural History: Remarks on the Bka' gdams glegs bam. In Studia Tibetica: Festschrift for P. K. Sørensen, eds. O. Czaja and G. Hazod, 411-444. Wiesbaden: Dr. Ludwig Reichert Verlag.

- forthcoming. Reprinting the Buddhist Classics: On the Production and Circulation of Blockprints. In Proceedings of the Conference Manuscript and Xylograph Traditions in the Tibetan Cultural Sphere: Regional and Periodical Characteristics, ed. O. Almogi.

Settis, S. 2005. Iconografia dell'arte italiana 1100-1500: una linea. Torino: Einaudi.

Silk, J. 1996. Notes on the History of the Yongle Kanjur. In Suhrllekhāh: Festgabe für Helmut Eimer, 153-200. Swisttal-Odendorf: Indica et Tibetica Verlag.

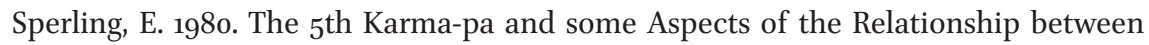
Tibet and the Early Ming. In Tibetan Studies in Honour of Hugh Richardson, eds. M. Aris and A. S. Suu Kyi, 280-9. Warminster: Aris and Phillips.

1982. The 1413 Ming Embassy to Tsong kha pa and the Arrival of Byams-chen Chos-rje Shākya Ye-shes to the Ming Court. Journal of the Tibet Society 2: 105-8.

Thaye, T. P. N. 1997. A Painter's Approach to Style. In Tibetan Art. Towards a Definition of Style, eds. J. Casey Singer and P. Denwood, 272-77. London: Laurence King.

Tucci, G. 1941. Indo-Tibetica. Vol. IV. Gyantse ed i suoi monasteri. Roma: Reale Accademia d'Italia.

-1949. Tibetan Painted Scrolls. Roma: La Libreria dello Stato.

Wangdu, P. 2012. A Study of mKhyen brtse chen mo dge bsnyen rnam rgyal, his mural paintings at Gong dkar chos sde and the mKhyen lugs school of Tibetan Painting. 
In The Arts of Tibetan Painting. Recent Research on Manuscripts, Murals and Thangkas of Tibet, the Himalayas and Mongolia (11th-19th century). PIATS 2010: Proceedings of the Twelfth Seminar of the IATS Vancouver, 2010, ed. A. Heller. http:// asianart.com/articles/wangdu.

Watt, J. C. Y. and D. P. Leidy. 2005. Defining Yongle: Imperial Art in Early FifteenthCentury China. New York: The Metropolitan Museum of Art.

Weidner, M. 2009. Beyond Yongle: Tibeto-Chinese Thangkas for the Mid-Ming Court. Artibus Asiae 69/1: 7-37.

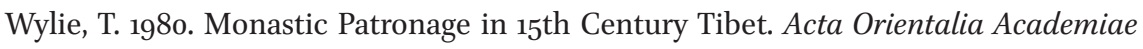
Scientiarium Hung. 34/1-4: 319-328.

1980b. Lama Tribute in the Ming Dynasty. In Tibetan Studies in Honour of Hugh Richardson, eds. M. Aris and A. S. Suu Kyi, 335-40. Warminster: Aris and Phillips. 